An ESRC Research Group

\title{
Unemployment in South Africa, 1995-2003: causes, problems and policies
}

\author{
GPRG-WPS-010
}

Geeta Kingdon and John Knight

Global Poverty Research Group

Website: http://www.gprg.org/

The support of the Economic and Social Research Council (ESRC) is gratefully acknowledged. The work was part of the programme of the ESRC Global Poverty Research Group. 


\title{
GPRG-WPS-010
}

\section{Unemployment in South Africa, 1995-2003: \\ Causes, Problems and Policies}

\author{
by \\ Geeta Kingdon \\ Centre for the Study of African Economies \\ University of Oxford \\ and \\ John Knight \\ Department of Economics \\ University of Oxford
}

January 2005

Acknowledgments: We are grateful to Haroon Bhorat, Daniela Casale, Dori Posel and Stephan Klasen for comments on this paper. Geeta Kingdon's time on this research work was funded by an ESRC grant under the Global Poverty Research Group at the Centre for the Study of African Economies. The research was originally commissioned by the National Institute for Economic Policy in South Africa. The views and opinions expressed are those of the authors alone. Our website is: http://www.csae.ox.ac.uk/, and the link to "Unemployment in South Africa: A microeconomic approach". 


\title{
Unemployment in South Africa, 1995-2003: Causes, Problems and Policies
}

\author{
By
}

Geeta Kingdon and John Knight

\section{Introduction}

It is our view that developments in the labour market hold the key to South African prosperity or penury. It is from the labour market that the income benefits from growing labour scarcity, or the threat to social and political stability from growing unemployment and underemployment, could emerge. The government response should be to keep this issue at the forefront and to pursue whatever policies will improve labour market outcomes.

Our primary concern in this paper is with unemployment and the informal employment that often disguises unemployment. However, in order to understand these phenomena it is necessary to consider a range of related indicators such as the adult population, the labour force, labour force participation, employment, distinguishing here between formal and informal employment, or between wage- and self-employment, and real wages and incomes.

Labour market data in South Africa are not without problems. Data collected in the early post-apartheid period are problematic for various reasons such as differing sampling, noncoverage of former 'homelands' in some surveys, small samples, etc. '. Moreover, comparability over time is undermined both by changing questions between the various surveys particularly as between the October Household Surveys (OHS) and Labour Force Survey (LFS), and by changes in the way employment and unemployment are derived from the questions in the different surveys (Casale and Posel, 2002). The definition of the 'informal sector' also changed in 1997. Further, population estimates change at every census so that when the weights are revised in each 5 year period, recent statistics require reestimation with the revised weights, though such revisions usually make only relatively minor differences in most statistics. Lastly, labour market data display some inexplicable large fluctuations - for instance employment figures rise sharply (by 10.4\%) in a single year between 1998 and 1999, employment in subsistence agriculture rose and dipped over 19992001 and there are large fluctuations from year to year in the numbers employed in the informal sector on a comparable definition between 1997 and $2002^{2}$. It is, thus, hazardous to make categorical statements about labour market changes over time in South Africa. This hazard is somewhat reduced if one takes a longer term view than to look at year-on-year changes. This is what we do below. Nevertheless, our presentation is intended not to be seen as an accurate reflection of specific labour market numbers but rather as a description of broad labour market trends. We use mostly the October Household Survey 1995 (OHS95) and the Labour Force Survey, September 2003 (LFS03).

In its starkest terms, the issue is depicted in Table 1. The problem is that the economy is unable to absorb productively all the current labour force or all the increment to the labour force. In the near-decade after the advent of democracy (1995-2003), the (narrow) labour force grew by 4.6 million and the broad labour force by 6.3 million (both by over $5 \%$ per

\footnotetext{
${ }^{1}$ Klasen and Woolard, 2000; Casale and Posel, 2002.

${ }^{2}$ See Bhorat, 2003, p.4; Altman, 2002, p6; and Devey, Skinner and Valodia (2003).
} 
annum). By contrast, over the same period, wage employment rose by only 1.3 million (1.8\% per annum), self-employment grew by 0.7 million ( $5.1 \%$ per annum), and narrow and broad unemployment grew by 2.6 and 4.3 million respectively (both above $9 \%$ per annum). Over that period the unemployment rate rose from 17 to $28 \%$ on the narrow definition and from 29 to $42 \%$ on the broad definition. South Africa now has one of the highest rates of unemployment in the world even on the official narrow (but potentially misleading) definition. Informal sector employment also grew to absorb some of the increased labour force.

Table 1

Summary of labour market outcomes, 1995-2003

\begin{tabular}{|lrrrr|}
\hline & $\begin{array}{r}\mathbf{1 9 9 5} \\
\text { OHS }\end{array}$ & $\begin{array}{r}\mathbf{2 0 0 3} \\
\text { LFS }\end{array}$ & $\begin{array}{r}\text { Change } \\
(\mathbf{0 0 0})\end{array}$ & $\begin{array}{r}\text { Change } \\
(\boldsymbol{\%} \text { p.a. })\end{array}$ \\
\hline & & & & \\
Labour Force, narrow (000) & 11628 & 16192 & 4564 & 4.2 \\
Labour Force, broad (000) & 13667 & 19954 & 6287 & 4.8 \\
Wage employment (000) & 8231 & 9509 & 1278 & 1.8 \\
Self employment (000) & 1421 & 2111 & 690 & 5.1 \\
Unemployment, narrow (000) & 1976 & 4570 & 2584 & 11.0 \\
Unemployment, broad (000) & 4015 & 8332 & 4317 & 9.6 \\
Unemployment rate, narrow (\%) & 17 & 28 & 11 & - \\
Unemployment rate, broad (\%) & 29 & 42 & 13 & - \\
Real earnings in wage employment, 2000 prices & 3191 & 2805 & -386 & -1.6 \\
Real earnings in self employment, 2000 prices & 6866 & 2610 & -4256 & -11.4 \\
& & & & \\
\hline
\end{tabular}

Source: Tables 6 and 7 below.

The growing divergence between labour supply and demand inevitably had a depressing effect on market-determined real wages. However, the wage sector, and in particular the formal wage sector, was relatively protected, so pushing the burden of adjustment onto the self-employment sector, especially that part of it which had relatively free entry. Whereas real wages fell by $1.6 \%$ per annum (and formal sector real wages by $0.5 \%$ per annum over the period 1997-2003), self-employment incomes fell dramatically in real terms, by $11.4 \%$ per annum (and informal sector real wages by $7.8 \%$ per annum over those six years). The growth of large parts of this sector - with underemployed people eking out a living - is a sign of labour market failure rather than of success.

The theoretical framework for economists to bear in mind is shown in Figure 1. On the vertical axis is the wage rate ( $w_{f}$ and $w_{i}$ for the formal and informal sector respectively), and on the horizontal axis is the labour force, $L L^{\prime}$, assumed to be constant. The curve $M P L_{f}$ shows the demand curve, based on the marginal product of labour, in the formal sector. The curve $M P L_{i}$, measured from the right hand origin, shows the marginal product of labour in the informal sector. The exogenously given formal sector wage exceeds the competitive wage 
(which would be determined by the intersection of the curves $M P L_{f}$ and $M P L_{i}$ ) and the market determined informal sector wage falls short of it. Formal sector employment is given by $L F$, informal sector employment is shown by $L$ ' $I$, and residual unemployment is the length FI. The amount of informal sector employment is determined by several factors:

opportunities $\left(M P L_{i}\right)$, barriers to entry, the disutility of work, and the perceived benefits of search unemployment. In 2003 the shares of $L F, L ' I$ and $F I$ in the total (broad) labour force were 38, 20 and 42\% respectively: broad unemployment actually exceeded formal sector employment. The ratio of $w_{f}$ to $w_{i}$ was no less than 3.4 to 1 (Table 7). Over time the labour force (the length $L L^{\prime}$ ) increased rightwards more than the curve $M P L_{f}$ shifted rightwards. We shall use this theoretical framework below.

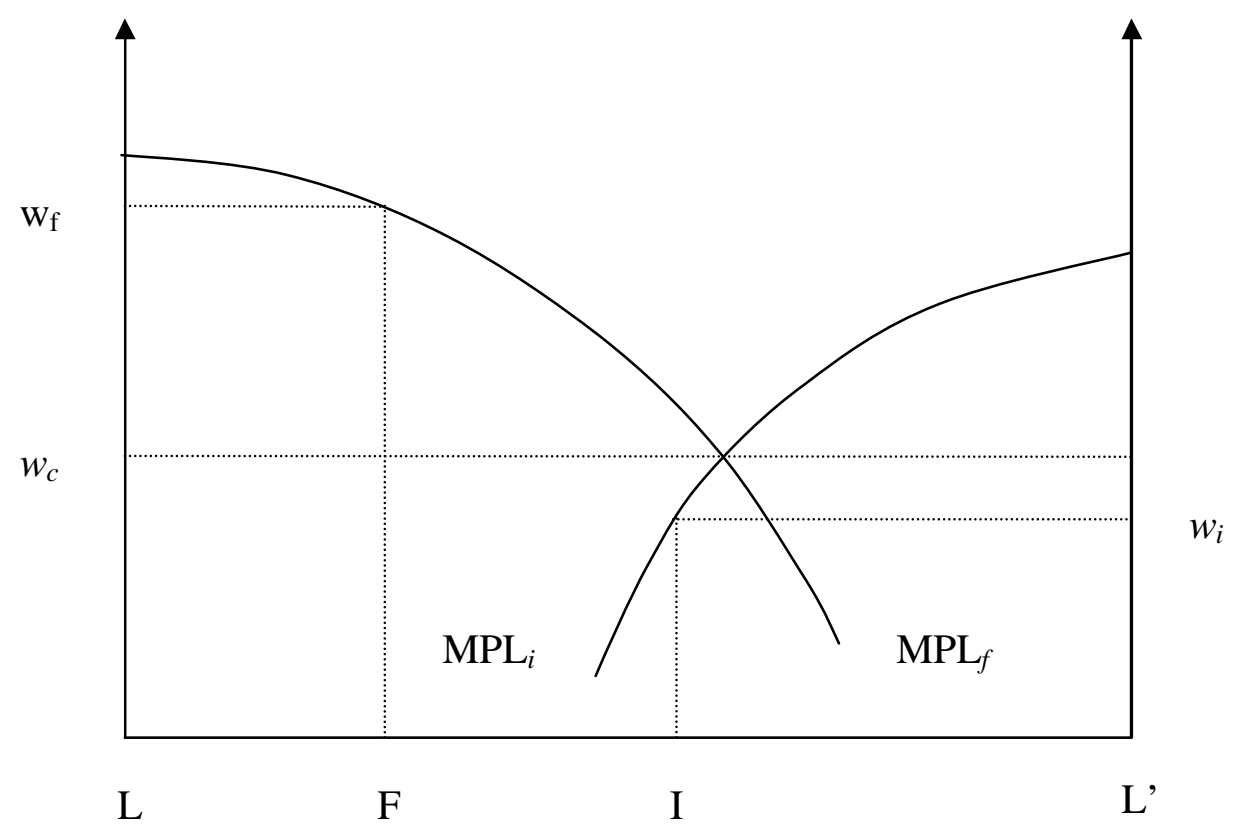

Figure 1

We must set this picture against the economist's view that, given enough competition, the labour market will clear at the natural rate of unemployment, voluntarily chosen. On this view, unemployment should not go on rising and rising. So why has it risen? The superficial answer is labour market rigidities - whether they are due to trade unions, or bargaining councils, or profit-maximising interventions by employers (the efficiency wage and labour turnover arguments as to why wages may be set above the market-clearing levels). In reality, however, it is the sheer speed of divergence between the growth of the labour force and the growth of formal sector employment (the divergence over the period 1997-2003 being nearly $4 \%$ per annum) that is the underlying cause. This puts great strain on the necessary downward wage adjustment process and inevitably meets resistance. Nevertheless, the wage rigidities of the formal sector exacerbate the problem by narrowing the segment of the labour market on which the burden of adjustment is placed. Given constraints on the opportunities for profitable informal sector activities, the result has been rising unemployment. 
In Section 2 we examine labour force growth in more detail and in Section 3 formal sector employment. Our main topic, unemployment, is covered in Section 4 and informal sector employment in Section 5. Section 6 turns to the policy issues.

\section{Labour force growth}

The South African labour force has grown remarkably rapidly: over $4 \%$ per annum is extremely unusual in international terms (Table 2). There are three possible explanations: inmigration, rapid natural increase in the number of working-age people, and increased labour force participation. In-migration is difficult to quantify as much of it is informal or illegal. Only part of the explanation is a rapid rate of increase in the adult population, whether due to natural increase or net in-migration. We see that this grew by $2.7 \%$ per annum over the period 1995-2003 whereas the labour force grew by $4.2 \%$ per annum on the narrow definition of unemployment and by $4.8 \%$ on the broad definition. The labour force participation rate rose from 48 to 54\% (narrow) over the eight years and from 56 to $67 \%$ (broad). We cannot rule out the possibility that labour force growth is exaggerated by changing definitions, changing coverage, or sampling errors. Nevertheless, the labour force appears to have grown at a daunting pace.

Table 3 shows that the growth of the labour force has been the greatest among the African population group. Female participation rate rose by fully 15 percentage points and the male rate by 5.2 percentage points in a mere 8 year period. The increase in participation rates for both men and women is likely due to the lifting of apartheid restriction on movement to urban areas and the new possibilities of employment that this was perceived to open. The end of apartheid and the better occupational attainment possible for non-white groups and women (partly due to employment equity legislation) is likely to have raised returns to employment for a significant section of the population. Education levels have risen and participation rates typically increase with education level, particularly so for women. Lastly, the significantly higher increase in female than male participation rate appears to be because of a decline in women's access to male income due to increased unemployment among males, the HIV epidemic and increased female headship due to changes in household structure ${ }^{3},{ }^{4}$.

\footnotetext{
${ }^{3}$ Casale and Posel (2002) show that the percentage of working-age women living with at least one employed male in the household fell from 53\% in 1995 to $44 \%$ in 1999, female headship increased from $28 \%$ in 1995 to $34 \%$ in 1999 and the percentage of women reported to be married fell from $39.5 \%$ in 1995 to $35.2 \%$ in 1999.

${ }^{4}$ It is well known that the Labour Force Surveys made a greater effort to capture informal work than did the previous October Household Surveys. It might be thought possible that, in doing so, some persons who worked in very informal employment (such as subsistence agriculture) and who may previously have been classified as non-participants now counted as labour force participants. However, such a change in their recorded status would not lead to an increase in unemployment since they would be included as employed. The fact that unemployment - reliably measured across the years - has increased suggests that the increase in labour force participation rates is not largely due to better capture of informal work that was previously overlooked. Moreover, much of the 15 percentage point increase in female labour force participation rates occurred before the introduction of the LFS, i.e. before serious attempts were made to improve questions to capture informal work (though there were some minor changes in employment questions in 1996 and 1997 OHSs). Casale and Posel (2002) show that between the 1995 and 1999 October Household Surveys, female broad labour force participation rate rose by 13 percentage points, from $47.8 \%$ to $60.8 \%$. Thus, the bulk of the increase in labour force participation rates is not due to better capture of participants in later surveys.
} 
Table 2

South African population of working age, not economically active, labour force and labour force participation rates, 1995-2003

\begin{tabular}{|c|c|c|c|c|}
\hline & $\begin{array}{l}1995 \\
\text { OHS } \\
\end{array}$ & $\begin{array}{c}2003 \\
\text { LFS } \\
\end{array}$ & $\begin{array}{c}\text { Change } \\
(000)\end{array}$ & $\begin{array}{l}-2003 \\
(\% \text { p.a. })\end{array}$ \\
\hline Population 15-65 (000) & 24232 & 29917 & 5685 & 2.7 \\
\hline \multicolumn{5}{|l|}{ Narrow measure } \\
\hline Labour force $(000)$ & 11628 & 16192 & 5464 & 4.2 \\
\hline Not economically active $(000)$ & 12604 & 13725 & 1121 & 1.1 \\
\hline Labour force participation rate $(\%)$ & 48 & 54 & 6 & --- \\
\hline \multicolumn{5}{|l|}{ Broad measure } \\
\hline Labour force $(000)$ & 13667 & 19954 & 6287 & 4.8 \\
\hline Not economically active (000) & 10565 & 9963 & -602 & -0.7 \\
\hline Labour force participation rate $(\%)$ & 56 & 67 & 11 & --- \\
\hline
\end{tabular}

Source: Table 6 below. Working age population equals (labour force)/(labour force participation rate).

The figures for the recent period 2000-2003 (using the first and the most recent LFS) present a less daunting picture. In this period, the narrow labour force grew by only $0.8 \%$, and the broad labour force by $2.6 \%$, all expressed per annum. It is important to know how much of the recent (post-2000) slow-down in the increase of labour force participation rate was due to HIV/AIDS, and how much of the fall was due to worker discouragement, i.e. people stopped seeking work or even aspiring to it.

Table 3

Labour force participation rates $(\%), \mathbf{1 9 9 5 - 2 0 0 3}$

\begin{tabular}{|c|c|c|c|c|c|c|c|c|c|}
\hline & \multicolumn{3}{|c|}{ Males } & \multicolumn{3}{|c|}{ Females } & \multicolumn{3}{|c|}{ Total } \\
\hline & 1995 & 2003 & $\begin{array}{c}\text { Change } \\
\text { percentage } \\
\text { points }\end{array}$ & 1995 & 2003 & $\begin{array}{c}\text { Change } \\
\text { percentage } \\
\text { points }\end{array}$ & 1995 & 2003 & $\begin{array}{c}\text { Change } \\
\text { percentage } \\
\text { points }\end{array}$ \\
\hline African & 59.9 & 69.2 & 9.3 & 44.3 & 63.1 & 18.8 & 51.8 & 65.9 & 14.1 \\
\hline Coloured & 72.1 & 75.7 & 3.6 & 55.4 & 64.8 & 9.4 & 63.5 & 69.8 & 6.3 \\
\hline Indian & 75.7 & 77.3 & 1.6 & 39.2 & 51.9 & 12.7 & 57.2 & 64.3 & 7.1 \\
\hline White & 72.1 & 79.8 & 7.7 & 47.9 & 61.5 & 13.6 & 59.9 & 70.4 & 10.5 \\
\hline All & 65.9 & 71.1 & 5.2 & 47.8 & 62.8 & 15.0 & 56.4 & 66.7 & 10.3 \\
\hline
\end{tabular}

Source: October Household Survey, 1995; Labour Force Survey, 2003. 
Looking to the future, it is necessary to consider the likely effect of the HIV/AIDS epidemic on trends in the labour force. For the population as a whole, HIV infection rates are forecast to peak at $17 \%$ in 2006 and AIDS-related deaths about 5 years later, when the AIDS mortality rate will be $1.8 \%$ (Quattek 2000). However, the peak HIV infection rate will be higher for economically active people, at $26 \%$. It will be as high as $30 \%$ for unskilled and semi-skilled workers but even the highly skilled will have a peak infection rate of $13 \%$. In the absence of AIDS, the growth of the South African labour force would be $1.9 \%$ per annum over the decade 2003-2013, but in the AIDS-inclusive scenario it is forecast to be $0.8 \%$ lower, at $1.1 \%$ per annum.

Because the rate of growth of the economy is sure to be adversely affected in various complex ways by the HIV/AIDS epidemic, we cannot simply subtract the projected slower growth of the labour force in order to measure the effect on unemployment, i.e. unemployment will not be lower by the same amount as the labour force. Any projection of employment and unemployment would have to be based on numerous untestable assumptions. The study by Quattek (2000), which projects employment growth as slower by $1.2 \%$ per annum over the decade 2003-2013 on account of the disease, and unemployment to be 9.2 percentage points lower than it would otherwise be in 2013, suggests the possible orders of magnitude.

\section{Formal sector employment}

A distinction can be made between the formal sector (comprising firms that are formally registered) and the (unregistered) informal sector. The insider-outsider theory of labour economists is helpful here: formal sector employees can be regarded as 'insiders' and residual workers, comprising those in the informal sector (which serves as a residual labour 'sponge') and the unemployed, as 'outsiders'. South African insiders fall within the scope of the industrial relations regulations, including recognition of trade unions and collective bargaining, the right to strike, protection against dismissal, and minimum standards concerning hours of normal and overtime work, minimum wages, and minimum leave provisions. There is provision for exemptions, generally granted on the basis of small scale and inability to pay. The informal sector workers fall outside the labour regulation system, and generally receive much lower income. The simple ratio of monthly income per worker of the formal to the informal sector in 2003 was 3.4 to 1 (Table 7); Kingdon and Knight (2004a) report that in 1993, this ratio was 3.5:1 but that after standardising for the different average personal characteristics of workers in formal and informal sectors, the formal-informal earnings gap fell by between 50 and $64 \%$ depending on whether OLS or selectivity-corrected earnings functions were used, i.e. the ratio was about halved. Inevitably, in some respects, the two groups have conflicting interests and are in competition with each other.

The formal sector in South Africa possesses the characteristics of a middle-income country, whereas the informal sector has those of a poor, less developed country. Like other middleincome countries, especially those with a mineral economy, the formal sector has a comparative advantage in natural resource-intensive, or capital-intensive, or skill-intensive manufacturing. It cannot compete with the East Asian economies in low-wage unskilledlabour-intensive manufacturing. And any successful labour-intensive manufacturing by the informal or small-scale sector, leading to its growth, is sure to lead to its formalisation. 
There are two sources of information on formal sector employment: one based on the OHS and LFS sample household surveys, and the other based on the enumeration of employees in enterprise surveys. Both are prone to be inaccurate. The former can suffer from sampling error and the need to adjust figures periodically in the light of new population census estimates. The latter suffer from non-reporting and may miss casual employees of registered enterprises.

Table 4 shows formal sector non-agricultural employment in 1997 (the earliest year for which comparable figures are available) and for 2003 (the latest year). It is based on OHS and LFS sources. Over those six years formal sector employment increased by 702,000. This implies an annual average rate of growth of $1.6 \%$. This figure is probably more accurate than the one obtained from the enterprise surveys such as the annual Survey of Employment and Earnings, which capture employment only in the large businesses (those with a VAT turnover of more than R300,000 per annum) which actually show a fall in employment over that period. Employment in the informal sector grew more rapidly than the formal sector, by $1,088,000$, equal to $8.4 \%$ per annum.

Similar results are obtained by comparing wage employment and self employment over the period $1995-2003$. Wage employment grew by 839,000 , or by $1.3 \%$ per annum. Selfemployment grew more, and faster: 991,000 and 11.2\% per annum. Agricultural employment - less accurately recorded, especially subsistence agriculture - is shown separately; it rose very slowly.

Table 4

Formal and informal sector employment, wage- and self-employment, and total employment, 1995, 1997 and 2003 (000s)

\begin{tabular}{|lccccr|}
\hline & $\begin{array}{c}\mathbf{1 9 9 5} \\
\text { OHS }\end{array}$ & $\begin{array}{c}\mathbf{1 9 9 7} \\
\text { OHS }\end{array}$ & $\begin{array}{r}\mathbf{2 0 0 3} \\
\text { LFS }\end{array}$ & $\begin{array}{r}\text { Change } \\
(\mathbf{0 0 0})\end{array}$ & $\begin{array}{r}\text { Change } \\
(\boldsymbol{\%} \text { p.a. })\end{array}$ \\
\hline Non-agricultural & & & & & \\
Formal & & 6839 & 7541 & 702 & 1.6 \\
Informal & & 1750 & 2838 & 1088 & 8.4 \\
Wage employment & 7845 & & 8684 & 839 & 1.3 \\
Self employment & 703 & & 1694 & 991 & 11.2 \\
Agricultural & 944 & & 1010 & 66 & 0.8 \\
& & & & & \\
Total & 9631 & & 11579 & 1948 & 2.3 \\
\hline
\end{tabular}

Source: Casale et al (2005), table 1. For 2003, the authors use the March round of the LFS data.

Notes: 1.Estimates for 1995 and 1997 are weighted using the 1996 population weights and for 2003 the 2001 population weights. 2. Domestic service work is treated as informal sector wage employment.

Overall, total employment increased by almost 2 million jobs, i.e. by $2.3 \%$ per annum, over the eight years. However, we have seen that the (strongly overlapping) formal and wage employment sectors grew disappointingly, and that they lost ground to the lower-paying informal self-employment sector which, in its free-entry parts, served as a residual sponge.

It is apparent that much of the formal sector pays well above the level of competitively determined market wages. Do these relatively high wages adversely affect the level of 
employment in the formal sector? The wage-employment elasticity - the proportionate fall in employment that occurs in response to a unit proportionate rise in the wage rate - is therefore an important issue. It has attracted considerable research attention. (surveyed in Bhorat, Lundall and Rospabe, 2002).

A World Bank study (Fallon and Lucas 1998) showed a long run weighted mean elasticity for black workers in the formal sector of -0.71 (after three years, when adjustment was likely to be complete). This implies that a $10 \%$ increase in the wage rate results, in due course, in a $7 \%$ decrease in black employment. Other researchers have produced similar results: Bowles and Heinz (1996) obtained -0.73 , and Bhorat and Leibbrandt also in the region of -0.7 . Fields, Leibbrandt and Wakefield (1999) obtained an elasticity for the period 1994-8 of -0.53 for the private sector as a whole; the elasticity was particularly high in mining and quarrying $(-0.96)$ and construction (-0.63).

The implication of these studies is that there is indeed a difficult policy trade-off between wages and employment. The 'real wage resistance' shown in the formal sector over the last decade has involved the loss of jobs. However, it is also clear from the estimated elasticities that greater wage flexibility would have been unable to prevent the rise in unemployment. The problem is essentially the dynamic one of inadequate growth of formal sector demand for labour.

\section{Unemployment}

In this section we consider the following questions: (1) is the broad or the narrow definition of unemployment the more appropriate? (2) how and why unemployment has risen (c) how have dimensions of unemployment changed? and (4) the active labour market policies that have been pursued to address unemployment.

\subsection{The definition of unemployment}

In South Africa, two different concepts of unemployment are used routinely: the strict (narrow) and the expanded (broad) definition. The broad definition accepts as unemployed those who did not search for work in a 4-week reference period but who report being available for work and say they would accept if a suitable job were offered. In 1998 the narrow concept was declared the 'official' definition of unemployment. While the South African statistical agency (Statistics South Africa, or StatsSA) continues to publish statistics for both the broad and the narrow definitions of unemployment, Department of Labour documents tend to report the narrow (official) rate of unemployment rather more. The narrow measure is also the only measure of unemployment reported in important sources, such as the South African Reserve Bank's website (http://www.reservebank.co.za/). Altman (2002) regards it as "unfortunate that broad definitions of unemployment are not much discussed anymore".

Yet, for the South African labour market, it has been argued that the broad measure of unemployment is the more accurate reflection of joblessness than the narrow measure. Kingdon and Knight (2005, forthcoming) investigate the issue in some depth. They use three new approaches to test the distinctness of the searching and non-searching unemployed states 
in conditions of high unemployment. They find, firstly, that in South Africa the nonsearching unemployed are, on average, significantly more deprived than the searching. The fact that they are not better-off casts doubt on the interpretation based on tastes (lack of desire for employment) and favours the interpretation that active search is discouraged (low prospective returns to search). This view is supported by evidence from a job-search logit model, which suggests that search is hampered by poverty, by the cost of job-search from remote rural areas (almost uniquely in the world, South Africa has higher rural unemployment than urban), and by high local unemployment. Secondly, the non-searching unemployed are not any happier than the searching unemployed. Their unemployment depresses their subjective wellbeing to the same extent as is the case for the searching unemployed, i.e. the non-searchers are no less pained by their joblessness than the searchers. This result proved to be robust to various checks. Finally, evidence on the wage-unemployment relationship indicates that local wage determination takes non-searching workers into account as genuine labour force participants. The searching and the non-searching unemployed are very close in terms of potential labour supply. These findings indicate that lack of search is due to discouragement and constraints such as poverty, rather than due to a weaker attachment to the labour market. Most analysts in South Africa seem to agree with this view, as seen from their focus on the expanded definition of the labour force in their papers and studies.

The de-emphasis on the broad measure in official circles may be because of pragmatism: even narrowly measured unemployment is a large enough worry. It is difficult to face up to the enormity of the South African unemployment problem in its totality. As the reality of the scale and unrelenting rise of unemployment has been grasped, it has become a matter of pragmatism that the limits of what the government can do about unemployment are acknowledged and priorities set for which section of the unemployed policy should target. For instance, it is now recognised that significant parts of the non-youth unemployed may be unemployable due to their lack of any previous employment experience, long duration of unemployment, and lack of skills ${ }^{5}$. Poswell (2003) concludes that it is important to distinguish between the unemployed in terms of future employability and advises that for the unemployable, the appropriate policy would be in terms of poverty alleviation whereas for those who have a greater probability of finding employment, the most helpful form of government assistance would be in targeted skills development and job creation.

\subsection{The rise in unemployment}

Table 5 shows a steady increase in unemployment rates over the eight-year period from 1995 to 2003. On the broad definition, which includes the 'discouraged' workers, the unemployment rate rose from $29 \%$ to $42 \%$, an increase of 13 percentage points over the eightyear period. On the narrow - less inclusive - definition, unemployment also rose by 13 percentage points, from $17 \%$ to $30 \%$. In other words, the extent of both searching and nonsearching unemployment rose equally. Thus, the problem of growing unemployment in South Africa is not merely a problem of the growth in non-searchers, i.e. growth in the number of persons who are sometimes characterised as only weakly attached to the labour market. Unemployment rose more for males (by 13.7 percentage points) than for females (11.5 percentage points). This is striking given that labour force participation rates increased more for women than men.

\footnotetext{
${ }^{5}$ Poswell (2003) and Bhorat (2002).
} 
Table 5

Distribution of the Labour Force in South Africa

\begin{tabular}{|c|c|c|c|c|c|c|c|c|}
\hline \multicolumn{9}{|c|}{ Using the broad definition of the labour force } \\
\hline & \multicolumn{2}{|c|}{$\underline{1995}$} & \multicolumn{2}{|c|}{$\frac{1999}{(\text { OHS }}$} & \multicolumn{2}{|c|}{$\frac{2003}{(\mathrm{LFS})}$} & \multicolumn{2}{|c|}{$\frac{\mathbf{2 0 0 3}}{(\overline{G H S})}$} \\
\hline & & $\%$ & ${ }^{6} 000 \mathrm{~s}$ & $\%$ & '000s & $\%$ & $600 \mathrm{~s}$ & $\%$ \\
\hline \multicolumn{9}{|l|}{ All persons } \\
\hline Employed & 9652 & 70.6 & 10369 & 63.8 & 11622 & 58.2 & 11247 & 57.3 \\
\hline Unemployed & 4015 & 29.4 & 5882 & 36.2 & 8332 & 41.8 & 8382 & 42.7 \\
\hline Labour Force & 13667 & 100.0 & 16251 & 100.0 & 19954 & 100.0 & 19629 & 100.0 \\
\hline LFP rate & & 56.4 & & 61.8 & & 66.7 & & 65.7 \\
\hline \multicolumn{9}{|l|}{ Males } \\
\hline Employed & 5892 & 77.5 & 6009 & 70.0 & 6436 & 64.3 & 6385 & 63.8 \\
\hline Unemployed & 1710 & 22.5 & 2573 & 30.0 & 3579 & 35.7 & 3624 & 36.2 \\
\hline Labour Force & 7602 & 100.0 & 8581 & 100.0 & 10015 & 100.0 & 10009 & 100.0 \\
\hline LFP rate & & 65.9 & & 68.1 & & 71.1 & & 71.0 \\
\hline \multicolumn{9}{|l|}{ Females } \\
\hline Employed & 3760 & 62.0 & 4353 & 56.8 & 5187 & 52.2 & 4862 & 50.5 \\
\hline Unemployed & 2305 & 38.0 & 3307 & 43.2 & 4753 & 47.8 & 4759 & 49.5 \\
\hline Labour Force & 6065 & 100.0 & 7660 & 100.0 & 9939 & 100.0 & 9621 & 100.0 \\
\hline LFP rate & & 47.8 & & 56.1 & & 62.8 & & 61.0 \\
\hline \multicolumn{9}{|c|}{ Unemployment rates based on the narrow definition of the labour force } \\
\hline All persons & & & & & 28 & & & \\
\hline Males & & & & & 25 & & & \\
\hline Females & & & & & 31 & & & \\
\hline
\end{tabular}

Note: The 1995 and 1999 figures are from the October Household Surveys for those years and are weighted using population estimates from the 1996 census. The 2003 figures are from the Labour Force Survey of September 2003. The GHS statistics are weighted using population estimates from the 2001 census. The narrow definition of the labour force excludes the so-called 'discouraged workers', i.e. those jobless persons who say they want work but who did not search in the past 4 weeks. LFP rate $=$ labour force participation rate in the working-age population.

Sources: StatsSA (1999), StatsSA (2000), StatsSA (2004), StatsSA (2004a). 
Table 6

Key Labour Market Trends: 1995 - 2003

\begin{tabular}{|c|c|c|c|c|c|c|c|c|c|c|c|c|c|c|c|c|c|c|}
\hline & \multicolumn{6}{|c|}{1995 (OHS) } & \multicolumn{6}{|c|}{2003 (LFS) } & \multicolumn{6}{|c|}{ Change (1995 - 2003) } \\
\hline & \multicolumn{2}{|c|}{ Total } & \multicolumn{2}{|c|}{ Male } & \multicolumn{2}{|c|}{ Female } & \multicolumn{2}{|c|}{ Total } & \multicolumn{2}{|c|}{ Male } & \multicolumn{2}{|c|}{ Female } & \multicolumn{2}{|c|}{ Total } & \multicolumn{2}{|c|}{ Male } & \multicolumn{2}{|c|}{ Female } \\
\hline & $\%$ & $000 \mathrm{~s}$ & $\%$ & $000 \mathrm{~s}$ & $\%$ & $000 \mathrm{~s}$ & $\%$ & '000s & $\%$ & '000s & $\%$ & $000 \mathrm{~s}$ & $\%$ & $000 \mathrm{~s}$ & $\%$ & '000s & $\underline{\%}$ & $000 \mathrm{~s}$ \\
\hline Broad definition & & & & & & & & & & & & & & & & & & \\
\hline Wage employment & 60.2 & 8231 & 70.8 & 5379 & 47.0 & 2852 & 47.7 & 9509 & 52.9 & 5302 & 42.3 & 4207 & -12.5 & 1278 & -17.9 & -77 & -4.7 & 1355 \\
\hline Self-employment & 10.4 & 1421 & 6.7 & 513 & 15.0 & 908 & 10.6 & 2111 & 11.3 & 1134 & 9.8 & 977 & 0.2 & 690 & 4.6 & 621 & -5.2 & 69 \\
\hline Employment & 70.6 & 9652 & 77.5 & 5892 & 62.0 & 3760 & 58.2 & 11622 & 64.3 & 6436 & 52.2 & 5187 & -12.4 & 1970 & -13.2 & 544 & -9.8 & 1427 \\
\hline Unemployment & 29.4 & 4015 & 22.5 & 1710 & 38.0 & 2305 & 41.8 & 8332 & 35.7 & 3579 & 47.8 & 4753 & 12.4 & 4317 & 13.2 & 1869 & 9.8 & 2448 \\
\hline Labour Force & 100.0 & 13667 & 100.0 & 7602 & 100.0 & 6065 & 100.0 & 19954 & 100.0 & 10015 & 100.0 & 9939 & 0.0 & 6287 & 0.0 & 2413 & 0.0 & 3874 \\
\hline LFP rate $(\%)$ & 56.4 & & 65.9 & & 47.8 & & 66.7 & & 71.1 & & 62.8 & & 10.3 & & 5.2 & & 15.0 & \\
\hline Narrow definition & & & & & & & & & & & & & & & & & & \\
\hline Wage employment & 70.8 & 8231 & 79.4 & 5379 & 58.7 & 2852 & 58.7 & 9509 & 61.5 & 5302 & 55.6 & 4207 & -12.1 & 1278 & -17.9 & -77 & -3.1 & 1355 \\
\hline Self-employment & 12.2 & 1421 & 7.6 & 513 & 18.7 & 908 & 13.0 & 2111 & 13.2 & 1134 & 12.9 & 977 & 0.8 & 690 & 5.6 & 621 & -5.8 & 69 \\
\hline Employment & 83.0 & 9652 & 87.0 & 5892 & 77.4 & 3760 & 71.8 & 11622 & 74.6 & 6436 & 68.5 & 5187 & -11.2 & 1970 & -12.4 & 544 & -8.9 & 1427 \\
\hline Unemployment & 17.0 & 1976 & 13.0 & 879 & 22.6 & 1097 & 28.2 & 4570 & 25.4 & 2187 & 31.5 & 2382 & 11.2 & 2594 & 12.4 & 1308 & 8.9 & 1285 \\
\hline Labour Force & 100.0 & 11628 & 100.0 & 6771 & 100.0 & 4857 & 100.0 & 16192 & 100.0 & 8623 & 100.0 & 7569 & 0 & 4564 & 0 & 1852 & 0 & 2712 \\
\hline LFP rate $(\%)$ & 48.0 & & 58.6 & & 38.3 & & 54.1 & & 61.2 & & 47.8 & & 6.1 & & 2.6 & & 9.5 & \\
\hline
\end{tabular}

Source: OHS 1995 (re-weighted using population estimates from Census 1996); LFS Sept. 2003. 
Table 6 presents a more detailed account of labour market movements just for 1995 and 2003. It makes clear one of the main reasons for the increase in unemployment over time, namely a dramatic increase in labour force participation rates, particularly among women. Table 6 also shows changes in the composition of employment over time, as between wage and selfemployment. An important trend is immediately apparent, namely a shift towards greater selfemployment. In 1995, 85.3\% of all employment was wage employment, an extremely high figure for a middle-income country. However, the pattern of employment creation over the next 8 years was different: over this period, only $64 \%$ of all net new employment was wage employment $(1,278,000$ jobs out of $1,970,000$ jobs $)$, as seen in the 'change' column. Indeed, among males all net new employment over the period was apparently in self-employment. Employment equity legislation which favours females may explain why women increased their share of total wage employment. The more rapid growth of self employment (which grew by $49 \%$ ) than of wage employment (which grew by only $15.5 \%$, though from a larger base), meant that by 2003 , only $81.8 \%$ of total employment was wage employment, compared with $85.3 \%$ in 1995. However, the increase in the share of self-employment may be overestimated because of the more efficient capture of subsistence agriculture and other informal activities in 2003 compared to 1995.

Unemployment has increased inexorably basically because economic growth - which averaged only $2.7 \%$ per annum and less than 1 percent per annum in per capita terms over this period was insufficient for the creation of enough jobs to absorb this unprecedented growth in the labour force. Table 2 shows that growth in total employment - wage and self-employment together - has been much lower than growth in the size of the labour force: while employment grew in absolute terms by nearly 2 million new jobs over this period, the size of the labour force grew by 6.3 million $^{6}$.

The consequence of this divergence between employment growth and labour force growth is the large increase in unemployment combined with some decline in real wages. Table 7 shows that, using evidence from available household survey data, mean real earnings (across employed persons of all races) fell in 2000 prices from 3014 to 2360 Rands per month between 1995 and 2003, a drop in real earnings of nearly 22 percent (Casale et. al., 2005). Because of the lognormality of the distribution of earnings, these arithmetic means are likely to provide a misleading impression of the changes in earnings: medians or geometric means are needed to account for the skewness of the earnings distribution. It is possible that the decline in median wages was actually greater since real earnings in formal work (the higher end of earnings) were more or less stable over the 8-year period and it is only real earnings in informal work (low paid work) that have fallen greatly. This is consistent with the fact that employment increases have been greatest in the informal sector, part of which is a more free-entry sector than the formal employment sector where wages have been better insulated from decline.

While another source - the Survey of Employment and Earnings (SEE) - shows an increase in real wages, it is not as representative as the earnings data from household surveys. Statistics South Africa's SEE - as reported in the South African Reserve Bank's Quarterly Bulletins shows that between 1995 and 2003, real remuneration per worker rose by 15.4\% (see Appendix Table 1). However, this survey covers only private and public enterprises "with a VAT turnover exceeding Rand 300,000 per annum in the formal non-agricultural business sector of the South African economy" (p3 in StatsSA, 2003c) and, as such, is not representative: it enables us to see

\footnotetext{
${ }^{6}$ Casale, Muller and Posel (2004) question that 2 million new jobs were created between 1995 and 2003. They estimate that up to 600,000 of the supposed new jobs, i.e. about one third of the total increase in employment, may be due to better capture of existing informal/part-time jobs such as in subsistence agriculture in the later October Household Surveys and particularly the Labour Force Survey, rather than because of new employment.
} 
earnings changes only in the relatively large formal sector, the sector likely to be better sheltered from market pressures to decrease real wages. We examined the Labour Force Survey of September 2003 to investigate this issue further ${ }^{7}$. Appendix Table 2 shows that VAT registered businesses are larger in size, have higher worker earnings, employ more white persons, have more wage workers (rather than self-employed persons) and are more likely to be registered companies. They are also more likely to be in sectors that are growing and where wages are more buoyant, such as financial services, rather than in sectors such as community and personal services, which are the more free-entry sectors where earnings are less protected. Businesses covered in the SEE also contracted employment over the period ${ }^{8}$ while we know that according to the more representative household surveys, overall employment rose.

\section{Table 7 \\ Nominal and Real Earnings (1995 - 2003) Rands per month}

\begin{tabular}{|c|c|c|c|c|c|}
\hline & \multicolumn{2}{|c|}{ Nominal earnings } & \multicolumn{2}{|c|}{$\begin{array}{c}\text { Real earnings } \\
(\text { base year }=2000)\end{array}$} & \multirow{2}{*}{$\begin{array}{l}\text { \% Change in } \\
\text { real earnings } \\
1995-2003\end{array}$} \\
\hline & Oct. 1995 & Mar. 2003 & Oct. 1995 & Mar. 2003 & \\
\hline Agricultural work & 500 & 743 & 690 & 608 & -11.9 \\
\hline Domestic work & 424 & 578 & 585 & 473 & -19.1 \\
\hline \multicolumn{6}{|l|}{ Self-employment } \\
\hline Formal & 10196 & 9270 & 14081 & 7599 & -46.0 \\
\hline Informal & 2427 & 1182 & 5532 & 968 & -82.5 \\
\hline Total & 4971 & 3187 & 6866 & 2610 & -62.0 \\
\hline \multicolumn{6}{|l|}{ Wage employment } \\
\hline Formal & NA & 3645 & NA & 2986 & NA \\
\hline Informal & NA & 1088 & NA & 891 & NA \\
\hline Total & 2310 & 3425 & 3191 & 2805 & -12.1 \\
\hline $\begin{array}{l}\text { All employed } \\
\text { persons }\end{array}$ & 2182 & 2881 & 3014 & 2360 & -21.7 \\
\hline $\begin{array}{l}\text { Formal worker only } \\
(1997-2003)\end{array}$ & 2818 & 3957 & 3339 & 3241 & -2.9 \\
\hline $\begin{array}{l}\text { Informal workers } \\
\text { only (1997-2003) }\end{array}$ & 1286 & 1149 & 1523 & 941 & -38.2 \\
\hline
\end{tabular}

Source: Adapted from Table 3 in Casale, Muller and Posel (2005).

Kingdon, Sandefur and Teal (2004) show that the union wage premium increased in South Africa between 1993 and 1999. They find that even though unionised workers' wages fell a little in real terms, the gap between these and non-unionised wages grew since the latter fell much more in real terms. The suggestion is that union wages are more insulated than are nonunion wages from downward market pressures due to changes in labour supply. This is consistent with another form of wage inflexibility noted in Kingdon and Knight (1999) in South Africa, whereby union wages were inelastic but non-union wages quite responsive to variations in local unemployment rates in 1993.

\footnotetext{
${ }^{7}$ Although we could not isolate persons who worked in businesses with a turnover of greater than Rand 300,000 per annum, we could identify workers as belonging to businesses that were VAT registered and not VAT registered. ${ }^{8}$ Year on year, non-agricultural employment in the SEE sample of businesses - i.e. in the larger formal (VATregistered) businesses with turnover of $>300,000$ Rands per annum - fell by an average of $1.8 \%$ in every year between 1995 and 2003, except for 2002, when it rose by 0.1 percent over the previous year (p. S-158, SARB, Quarterly Bulletin, September 2004 and September 1999).
} 
Increases in unemployment together with the decline in real earnings among the employed in the post-apartheid period have led to increases in poverty. While the magnitudes of the estimates differ, there is a high degree of consensus that poverty rose over the post apartheid period. This is reflected in a number of studies using different surveys, questions, levels of aggregation (individual versus household as the unit of analysis), time periods and methods. Hoogeveen and Özler (2004), in a carefully conducted study, show that using the $\$ 2$ per day definition of poverty line, the headcount measure of poverty rose from $45 \%$ to $55 \%$ in rural and from $15 \%$ to $18 \%$ in urban South Africa between 1995 and 2000. In a similar vein, Casale et. al. (2005) show that on the $\$ 2$ per day poverty line, between 1995 and 2003, poverty rose from 9.6\% to $18.8 \%$ among all employed persons and from $18.1 \%$ to $42.0 \%$ among informally selfemployed persons. Leibbrandt, Levinsohn and McCrary (2004) find that real individual incomes fell between 1995 and 2000, the two years for which the Income and Expenditure Surveys are available. Van der Ruit and May (2003) estimate that on a PPP adjusted \$ 1 a day poverty line, the headcount measure rose from $11.5 \%$ to $19.8 \%$ between 1993 and 2000 . Finally, Meth and Dias (2004) also conclude that between 1999 and 2003, poverty increased. Increased unemployment, falling wages and resultant poverty are likely to be partly responsible for the increased levels of economic crimes in South Africa (SAPS, 2004; Masuku, 2003) ${ }^{9}$.

\subsection{The changing dimensions of unemployment}

This section examines changes in the incidence of unemployment across different worker groups, defined by age, gender, education, race and location. It considers three aspects of change in unemployment over the 1995-2003 period:

(a) how the distribution of unemployment has changed across worker groups

(b) how incidence of entry into unemployment from the employed state has changed

(c) how duration of unemployment has changed

Changes are examined by looking at descriptive statistics. However, since race, education and location are well correlated in South Africa, descriptive statistics are supplemented with simple binary probit equations of unemployment, entry into unemployment from previous work, and long-duration unemployment in Appendix 3. These permit one to say how likely a person with a given characteristic is to be unemployed (or to be in long-duration unemployment, or to be an entrant into unemployment from employment), holding constant all other characteristics.

\section{Changes in the incidence of unemployment}

Table 8 shows the changes over time in the racial, gender, educational, age and spatial distribution of unemployment. Overall unemployment increased by 13 percentage points. The Table shows that, among all population groups, broadly measured unemployment increased the most for Africans. It rose more for males than females and rose more for persons with junior and secondary levels of education than for those with none, primary and higher education. The change in unemployment by age is revealing: unemployment is particularly a problem among the young, i.e. the newer entrants into the labour market. Unemployment has risen the least in

\footnotetext{
${ }^{9}$ The SAPS website shows, for instance, that between 1994/95 and 2003/04, reported robbery with aggravated circumstances increased by $57.6 \%$, common robbery by $192.6 \%$ (from 32,659 to 95,551 ) and burglary at residential premises by $29.4 \%$, though burglary at non-residential premises fell by $26.2 \%$. Part of the increase in economic crime could be due to improved reporting of crime.
} 
the Western Cape, Eastern Cape and Mpumalanga. The fact that urban unemployment rates have risen somewhat faster than rural suggests increased rural to urban migration over time.

Table 8

Unemployment Rates, by worker group, 1995-2003

\begin{tabular}{|c|c|c|c|}
\hline & $\begin{array}{c}\text { Oct. } 1995 \\
\%\end{array}$ & $\begin{array}{c}\text { Sept. } 2003 \\
\%\end{array}$ & $\begin{array}{c}\text { Change } \\
\text { (percentage points) }\end{array}$ \\
\hline \multicolumn{4}{|l|}{ Race } \\
\hline African & 36.9 & 48.8 & 11.9 \\
\hline Coloured & 22.2 & 29.4 & 7.2 \\
\hline Indian & 13.2 & 20.7 & 7.5 \\
\hline White & 5.3 & 7.6 & 2.3 \\
\hline \multicolumn{4}{|l|}{ Gender } \\
\hline Male & 22.5 & 35.7 & 13.2 \\
\hline Female & 38.1 & 47.8 & 9.7 \\
\hline \multicolumn{4}{|l|}{ Education } \\
\hline None & 35.0 & 33.8 & -1.2 \\
\hline Primary & 36.3 & 44.7 & 8.4 \\
\hline Junior & 32.8 & 47.4 & 14.6 \\
\hline Secondary & 27.3 & 44.9 & 17.6 \\
\hline Higher & 6.0 & 13.0 & 7.0 \\
\hline \multicolumn{4}{|l|}{ Age } \\
\hline $16-20$ years & 59.4 & 76.7 & 17.3 \\
\hline $21-25$ years & 45.8 & 66.2 & 20.4 \\
\hline $26-35$ years & 30.4 & 43.1 & 12.7 \\
\hline $36-45$ years & 20.6 & 28.3 & 7.7 \\
\hline $46-55$ years & 17.6 & 23.4 & 5.8 \\
\hline 56-64 years & 11.9 & 15.8 & 3.9 \\
\hline \multicolumn{4}{|l|}{ Region } \\
\hline Rural & 37.9 & 49.7 & 11.8 \\
\hline Urban & 24.1 & 36.8 & 12.7 \\
\hline \multicolumn{4}{|l|}{ Province } \\
\hline Western Cape & 19.0 & 26.3 & 7.3 \\
\hline Eastern Cape & 42.0 & 49.4 & 7.4 \\
\hline Northern Cape & 27.6 & 39.1 & 11.5 \\
\hline Free State & 26.3 & 41.0 & 14.7 \\
\hline KwaZulu Natal & 34.1 & 45.0 & 10.9 \\
\hline North West & 33.1 & 47.1 & 14.0 \\
\hline Gauteng & 20.7 & 36.9 & 16.2 \\
\hline Mpumalanga & 33.9 & 41.5 & 7.6 \\
\hline Limpopo & 41.5 & 55.8 & 14.3 \\
\hline
\end{tabular}

Source: Authors' own calculations from OHS95 and LFS03. 
In OHS95, 31.3\% of the broadly unemployed reported having ever worked in the past for pay, profit or family gain. In 2003, 36.1\% of the unemployed reported having ever worked before. This increase is surprising given that a good part of the increase in unemployment over the period was due to new entrants to labour force (who have likely not worked before). However, the increase is likely explained by the fact that the question in LFS03 gives detailed examples of the kinds of activities that could be counted as work, including unpaid in family business, whereas the question in the OHS95 survey did not give any examples.

To what extent is entry into unemployment from employment due to involuntary quit? If entry into unemployment is from the employed state, it would be useful to know to what extent this is voluntary entry into unemployment (e.g. for job-search, for a better job) and to what extent it is due to involuntary job-separation due to retrenchment, lay-off, sacking, closure, etc.

Unfortunately, however, no data are available on the reasons for job separation in either OHS95 or LFS03 surveys so it is not possible to see how the incidence of involuntary job-separation changed in South Africa over the period. The OHS of 1994 did ask those unemployed who had worked before their reason for quitting work and this showed that only $25 \%$ had quit work voluntarily (Kingdon and Knight, 2004b). This may have been either quit into unemployment e.g. in search for a better job or it may have been quit into the out-of-the-labour-force state, e.g. for child-rearing/domestic/health reasons. For just over three-quarters of the previouslyemployed currently-unemployed persons, the reason for quit into unemployment was involuntary job-separation.

Kingdon and Knight (2004b) provide a cross-sectional analysis of how the incidence of previous work among the unemployed varies between different worker groups. They fitted a binary probit equation which showed that the probability of voluntary exit from employment among currently unemployed persons was 19 percentage points higher for females than males. This is plausible since women are likely to quit work for child-bearing, child-rearing and domestic reasons, and they may subsequently re-join the labour force and join the ranks of the unemployed. The study found that chances of voluntary exit from work among the unemployed were 22 percentage points higher for whites than Africans. This again is plausible since white persons face a tighter labour market which raises the chances of finding work quickly and makes them more mobile. Compared to Gauteng, the probability of voluntary quit into unemployment was 14 percentage points higher in the North West and 30 percentage points higher in the Northern Cape province.

However, the interesting question in a 10-year review would be whether there were changes over time in the incidence of entry into unemployment due to involuntary job-separation but it is not possible to answer this due to lack of data.

\section{Changes in the duration of unemployment}

There is no satisfactory data on unemployment duration in South Africa. What is available is the duration of uncompleted spells of unemployment of those currently unemployed. This is because there is effectively no panel data available on labour force participants in South Africa $^{10}$. Uncompleted spells are suggestive but they understate the true duration of

\footnotetext{
${ }^{10}$ While the Labour Force Surveys were intended to provide a rotating panel, the person identifiers are not coded in such a way that they can enable the user to achieve reliable matching of individuals from one round to another. Unfortunately, the KIDS data did not collect information on duration of unemployment. Cichello, Fields and
} 
unemployment. Moreover, even data on the uncompleted spells of unemployment are far from satisfactory: the data are in categorized rather than continuous form, the categories are not sensibly distributed and the question is asked only of the strictly unemployed in some surveys ${ }^{11}$.

Despite data deficiencies, it is of interest to examine unemployment duration with the available data for the searching unemployed. Table 9 shows the percentage of persons whose uncompleted duration of unemployment was greater than 3 years. The last column shows the change in that percentage over the period. It shows that long-duration unemployment rose by 4.6 percentage points or $15 \%$ (from $32.5 \%$ to $37.1 \%$ ). It also shows that the incidence of long unemployment duration has increased the most among Whites, persons with higher education, older labour force participants, and in the North West and Limpopo provinces. However, it is important to bear in mind the limitations of the data when interpreting these findings. It is possible that at any given duration of job-search, Africans become discouraged and become non-searchers while whites continue to search since their unemployment rates are much lower and probability of employment much higher.

To summarise the overall trends in the dimensions of unemployment in the 1995-2003 period:

(a) Overall, broad unemployment rose by 13.3 percentage points (i.e. by $45 \%$ ) from $29.4 \%$ to $42.7 \%$ and there were important changes in the distribution of unemployment across worker groups. Among the race groups, unemployment rose particularly highly for Africans; among the genders, particularly highly for males; among education levels, especially highly for persons with junior and secondary education; among age groups, for the young, especially those aged 16-25; and among provinces, unemployment rose particularly in Gauteng, Free State, North West and Limpopo.

(b) Due to lack of data, it is not possible to say whether and how much involuntary entry into unemployment from employment changed over time.

(c) Overall duration of narrow unemployment increased. It is not possible to compute changes in expanded unemployment due to lack of duration data for the discouraged workers in LFS03. The percentage of narrowly unemployed persons with long-duration of unemployment rose by 4.6 percentage point (or 15\%) from $32.5 \%$ to $37.1 \%$.

Leibbrandt (2004) find that 61\% of all African labour force participants were unemployed either in 1993 or 1998 or both, and that 249 (out of their total sample of 915 African labour force participants in KwaZulu Natal) were unemployed both in 1993 and in 1998. However, it would not be correct to infer (and they do not infer) that $27.2 \%$ of all African participants therefore had a 5 year long uncompleted duration of unemployment because we do not know whether these persons had employment in between.

${ }^{11}$ Firstly, the survey question asks how long an individual has been seeking work. Those who have become discouraged may interpret this to mean 'how long has the individual been searching for work' and may either not reply or reply that they have not searched, which is liable to be coded as the lowest duration category, e.g. 'less than one month'. Secondly, data is available only in categorized form, rather than as a continuous variable. For instance, in the 1995 OHS, the categories were less than a month, 1-6 months, 6-12 months, 1-3 years and >3 years. Thirdly, the categories of unemployment duration are not chosen in a way that leads to a good distribution of the unemployed across the categories: more than two-thirds of the unemployed have duration greater than 1 year, and nearly two-fifth have duration more than 3 years. The top two duration categories deserve breaking up into more detailed bands but instead, the Labour Force Surveys have provided sub-divisions of the categories for duration less than 1 year! Lastly, the question on duration of unemployment is asked only of the strictly unemployed in certain surveys, e.g. the Labour Force Survey of Sept. 2003. 
Table 9

Percentage of the narrowly unemployed whose uncompleted duration of unemployment is greater than 3 years,

by age, education, gender, region, and race, 1995-2003

\begin{tabular}{|c|c|c|c|}
\hline & $\begin{array}{c}\text { Oct. } 1995 \\
\%\end{array}$ & $\begin{array}{c}\text { Sept. } 2003 \\
\%\end{array}$ & $\begin{array}{c}\text { Change } \\
\text { (percentage points) }\end{array}$ \\
\hline \multicolumn{4}{|l|}{ Race } \\
\hline African & 38.1 & 40.2 & 2.1 \\
\hline Coloured & 12.9 & 21.1 & 8.2 \\
\hline Indian & 18.1 & 20.8 & 2.7 \\
\hline White & 9.5 & 21.6 & 12.1 \\
\hline \multicolumn{4}{|l|}{ Gender } \\
\hline Male & 32.0 & 34.5 & 2.5 \\
\hline Female & 35.3 & 41.0 & 5.7 \\
\hline \multicolumn{4}{|l|}{ Education } \\
\hline None & 41.3 & 43.3 & 2 \\
\hline Primary & 42.3 & 43.8 & 1.5 \\
\hline Junior & 34.4 & 38.3 & 3.9 \\
\hline Secondary & 25.0 & 34.1 & 9.1 \\
\hline Higher & 25.6 & 36.1 & 10.5 \\
\hline \multicolumn{4}{|l|}{ Age } \\
\hline $16-20$ years & 13.9 & 11.1 & -2.8 \\
\hline $21-25$ years & 21.8 & 24.6 & 2.8 \\
\hline 26-35 years & 39.0 & 45.6 & 6.6 \\
\hline $36-45$ years & 45.8 & 52.5 & 6.7 \\
\hline 46-55 years & 49.5 & 52.3 & 2.8 \\
\hline 56-64 years & 43.3 & 54.1 & 10.8 \\
\hline \multicolumn{4}{|l|}{ Region } \\
\hline Rural & 35.8 & 39.2 & 3.4 \\
\hline Urban & 32.6 & 37.2 & 4.6 \\
\hline \multicolumn{4}{|l|}{ Province } \\
\hline Western Cape & 14.4 & 21.8 & 7.4 \\
\hline Eastern Cape & 36.6 & 40.5 & 3.9 \\
\hline Northern Cape & 21.1 & 22.6 & 1.5 \\
\hline Free State & 39.4 & 43.3 & 3.9 \\
\hline KwaZulu Natal & 35.2 & 32.4 & -2.8 \\
\hline North West & 30.3 & 40.7 & 10.4 \\
\hline Gauteng & 40.1 & 43.5 & 3.4 \\
\hline Mpumalanga & 33.5 & 35.6 & 2.1 \\
\hline Limpopo & 34.0 & 46.9 & 12.9 \\
\hline
\end{tabular}

Source: Authors' own calculations from OHS95 and LFS03. 


\subsection{Policies to tackle unemployment}

The South African government has been much concerned about unemployment. It has pursued various active labour market policies to alleviate and address unemployment. A 10 year review is a useful juncture at which to reflect on the impact of labour market policies to address unemployment. We review two broad types of policies which have been pursued: Public works programmes (PWPs) and programmes to promote skills development. While systematic impact evaluations of these policies are yet to appear, there are some detailed case studies based on small samples which can shed some useful light on the effectiveness of these programmes.

\section{Public works programmes}

Public works programmes (PWPs) are a central part of the South African government's social protection framework for the unemployed. Policy documents indicate that the government attaches considerable importance to PWPs as a means to address unemployment. However, despite this policy prominence, little is known about the success of South African PWPs in meeting the employment promotion and poverty reduction objectives. While there is no national comprehensive evaluation, an in-depth study by McCord (2004) throws valuable light on the impact of PWPs on the labour market outcomes and poverty among programme participants in South Africa. This is based on a 2003 survey of about 700 households that contain current and recent participants in two different PWPs in Limpopo and Kwazulu Natal ${ }^{12}$. McCord's conclusions flow both from the evidence gathered in her survey as well as from insights in the existing literature, and show that currently designed PWPs have limited potential to address unemployment and poverty in South Africa.

The study chose two PWPs that were differently conceptualized, with different targeting and rationing mechanisms and different institutional implementation modalities. In both groups $25 \%$ of PWP workers gave up (mainly informal, survivalist) work in order to participate in the programmes. Security of employment was perceived as the core benefit of participation in the PWP where employment was permanent. However, the impact of the PWPs was limited because, firstly, one of the programmes was not well targeted towards high unemployment groups (on this also see Besley et. al., 2004) and, secondly, participation in neither of the two programmes brought the majority of households above the poverty line: even with PWP income, 99\% of the households in one PWP and $87 \%$ in the other still fell below the poverty line by a significant margin, though participation had obviously reduced the depth of poverty. The study highlights the impermanence of the poverty-reduction benefits in the PWP which did not provide permanent employment: only $1 / 3$ of former programme participants believed that employment in the PWP would have sustained anti-poverty benefits.

While the Department of Public Works characterises the post-PWP employment options as 'graduating to employment under normal conditions' evidence from McCord's survey suggests that workers tend rather to graduate to 'unemployment' under normal conditions, returning back to their original status of unemployment. The study argues that if the objective of the intervention is to promote subsequent labour market performance, then the youth unemployed should be targeted (although as the survey findings indicate such an intervention may be of limited benefit given the restricted nature of labour demand). If poverty alleviation or social protection are the objectives then older women or female headed households in remote areas may be the most appropriate target.

\footnotetext{
12 The method for impact evaluation was to compare income and employment outcomes of households before and during/after PWP employment in the 'treated' communities. The 'control' group was the total rural populations in the two provinces, which is less than ideal.
} 
McCord's study concludes that (a) employment opportunities in PWPs are grossly insufficient given mass unemployment in South Africa; (b) the targeting tools are inadequate; (c) PWP policy is based on the flawed implicit assumption that unemployment among the low and unskilled is a transitory rather than a chronic problem; and (d) PWP policy is also wrong in its supposition that supply side interventions can have a significant impact on unemployment when the underlying problem is the lack of employment growth.

The idea that PWPs can provide sustained employment was ruled out when the Code of Good Conduct for PWPs were agreed during tripartite negotiations between the union movement, the state and the public sector. The code permitted the payment of lower than minimum wages for PWP employees only on the condition that the employment offered under government PWP schemes is of short term duration and that workers are given training to compensate for the reduced wage. This conditionality made employment guarantee inadmissible and it shows the inherent tension between protecting the rights of the workers and the development of a PWP which can serve an effective unemployment alleviation function.

There is a crucial tension between policy expectations and programme reality in relation to PWPs. While policy documents (for instance the Expanded Public Works Programme document by the Department of Public Works, 2004) characterize public works as a work experience and training programme to improve labour market access and performance, at the end of which workers will graduate to employment under normal conditions, other analysts may be closer to the mark when they characterize PWPs as a social protection response to the challenge of 'unemployable' working age persons with no skills and geographical isolation (Abedian, 2004). McCord finds that the training component of PWPs is weak and that workers enter unemployment rather than employment.

McCord's study raises important issues about the design and conceptualization of PWPs that the government should ponder in order to better hone future PWP policies to achieve unemployment alleviation goals. In addition, it would be useful for the Department of Labour to commission a systematic national evaluation of the employment impact of different types of PWPs in South Africa. There is a good degree of consensus in the social sciences that the first-best method for impact evaluation - short of a natural or man-made experiment - is the so-called 'difference-indifference' method ${ }^{13}$. A careful evaluation of the impact of different types of PWPs on postparticipation employment probabilities would increase the evidence base on which future PWP policies can be based.

\section{$\underline{\text { Skills development programmes }}$}

Skills training has become a central plank in the government's labour market policy. In 1998 it enacted the National Skills Act and in 1999 created Sector Education Training Authorities (SETAs) to charge a skills levy from firms, to be repaid on the production of evidence by the firm that it is undertaking approved training for its workers. SETAs are also mandated to encourage Further Education and Training (FET) institutions in the provision of education and skills for work. The rationale for SETAs is skills shortages which according to firm reports act as a constraint to employment and growth in South Africa.

However, apart from a few studies (Felton, 2003; Lundall, 2003), relatively little is known and systematically documented about workplace skills in South Africa. Indeed there are apparent

\footnotetext{
${ }^{13}$ This involves subtracting the post-programme difference in outcomes of interest between treatment and control groups from the pre-programme difference in those outcomes between treatment and control groups.
} 
contradictions and gaps in the evidence base. On the one hand education levels are clearly low by the standards of successful exporters such as the East Asian Tiger economies and firm surveys report that firms do find it difficult to recruit professional, managerial and technical staff $^{14}$. On the other hand, however, observed behaviour of firms is somewhat inconsistent with the existence of a skills gap that constrains their employment/business growth:

1. Firm surveys show that vacancy rates are low. For instance, in the Johannesburg survey of firms in 1999, at least $75 \%$ of firms reported no vacancies (Chandra et. al., 2000, p. 41).

2. Firm surveys also ask whether firms engage in (in-house or contracted-out) skills training for their workers. The data show that, on average, only $33 \%$ of manufacturing workers in firms with more than 50 employees had received some form of training (Chandra et. al., 2000, p. 43).

3. Since 1999, there are financial incentives for firms to train workers: firms that engage in training can reclaim skill levies they paid to Sector Area Training Authorities (SETAs). However, as is well known, and somewhat surprisingly if firms face genuine skills shortages - SETAs have found that their large skilllevy revenues remain largely unclaimed by the firms.

4. Evidence from a much smaller but more probing qualitative survey (Felton, 2003) suggests that firms lack knowledge about what skills are lacking. This goes somewhat against the idea that firms perceive lack of skills as a major problem hindering their performance ${ }^{15}$.

5. Unemployment among college and university graduates has been increasing. This can be seen in Table 8. The unemployment rate among secondary school graduates rose from $27 \%$ to $45 \%$ and, among persons with higher education, it rose from $6 \%$ to $13 \%$. The problem of skills in South Africa could now be more a problem of the low quality of education than of the availability of educated workers. There is some support for this in van der Berg (2001).

Firms' well documented reluctance to undertake skills training themselves may be because the skills that are lacking are of a generic nature - such as the desired degree of numeracy, literacy, communication skills, problem solving, initiative-taking etc. - and firms would not be able to sufficiently recoup the expense of investment in such skills if the trained worker quits the firm soon after training ${ }^{16}$. If this is so, then there may be a case for government intervention in skills, though such a case has not yet been well articulated in South Africa.

\footnotetext{
${ }^{14}$ Surveys of South African firms (World Bank surveys of firms in Johannesburg and Durban in 1999 and 2003 , and a President-Office commissioned national survey of 1400 firms conducted by the University of Stellenbosch in 2000) have questions on firms' perceptions of skills shortages in different occupational categories, their skillstraining expenditures, types of skills-training institutions they consider most useful, their views on the employmenteffects of the Skills Development Act, etc. This information sheds valuable light on some of the questions about skills in South Africa. See Bhorat and Lundall (2002), Chandra et. al. (2000) and Devey et. al. (2003) for more information about these surveys. The reported difficulty in recruiting higher-skilled staff is likely to be partly due to the emigration of skilled persons and due to employment-equity related requirements of racial balance in all occupation groups within any firm.

${ }^{15}$ Felton (2003) reports various findings that cast some doubt on the importance of skills shortages. For instance, he finds that businesses find it hard to identify or articulate their skills needs. E.g. "interviews with those with considerable experience and expertise suggest that, for example, employers know very little about skills and they are very rarely able to identify or articulate exactly what they require" (p.36). Similarly, evidence on page 44 suggests that firms' behaviour is not consistent with the view that they perceived serious skill shortages. The report concludes (p. 52) that "at present it appears that institutions tend to respond to skills policy in two ways (a) to make superficial changes to current practice and argue that this is skills development (b) to ignore much of what is going on but feign compliance... it is clear that much of the skills development strategy has not been understood nor has commitment been secured".

${ }^{16}$ The theoretical labour economics literature on skills training states that firms will invest only in firm-specific and not in generic skills of their workers since returns to generic skills may be reaped by other firms if the worker quits
} 
There is a lack of clarity in the debate about skills in South Africa, for instance is the objective of government skills interventions to (a) help unemployed individuals gain employment or (b) to promote worker productivity (and hence firm profits and economic growth), or both. The policy concern with skills is presumably because skills development is thought to promote both employment and worker productivity/firm profits/economic growth.

The belief that skills development is important for alleviating unemployment in South Africa arises from the general observation that unemployment rates are the lowest among educated persons in South Africa. The suggestion that lack of skills hinders employment of individuals and thus contributes to the high unemployment rates has also been challenged. However, whether skill upgrading alleviates unemployment is potentially testable. We are not aware of any South African studies that evaluate the impact of skills development on either an unemployed individual's employment chances or on worker productivity. In order to buttress the case for policy intervention in skills, the government needs to ask whether and what type of skills training improves the employment chances of unemployed persons. Such studies are badly needed to inform enlightened policy making. There is now a voluminous literature using state of the art evaluation techniques, such as propensity score matching techniques and even randomised experiments that permit the use of a 'difference in difference' approach to impact evaluation; for example, see Bryson et. al. (2002), Tan (2003) and Galasso, Ravallion and Salvian (2002) among many others. It would be useful for the Department of Labour to commission such impact evaluations.

\section{Informal sector employment}

Being the residual sector into which workers can in principle move, the informal sector can be predicted to have two features. First it should have grown rapidly in response to the growing divergence between labour supply and formal sector labour demand. Second, the free-entry parts of the informal sector should contain a good deal of underemployment and poverty.

As defined by the South African statistical agency, the 'informal sector' absorbed a mere $15.7 \%$ of the workforce in 1997 and, although the figures are unreliable (Devey et. al., 2003), the size of the informal sector shows growth in recent years, rising to $18.8 \%$ by 2002 . Despite this growth, however, South Africa remains an international outlier in terms of the small size of its informal sector: as seen in Table 10 (taken from Kingdon and Knight, 2004a), its ratio of informal sector employment to unemployment is close to 1, whereas the averages for Sub Saharan Africa, Latin America and Asia are 4.7, 7.0 and 11.9 respectively. The high level of joblessness begs the question why the mass of the unemployed do not join the informal sector, as in most other developing and middle-income countries. This is a quandary deserving attention.

the firm too soon after receiving training. This will result in under-investment in generic skills, below the socially optimal level and it provides the rationale for government intervention/incentives for training in general skills. This is a simple but powerful theoretical insight of relevance to debates about the appropriate role of government in promoting skills training. To our knowledge, it appears nowhere in the South African skills-gap debate. Yet, this insight has useful policy implications. Profit-maximising firms already have an interest in providing firm-specific skills to their own workers; thus, the skills shortage presumably manifests itself as a deficit of generic skills (this is testable), and it is only in the promotion of generic skills that government would normally engage. The usefulness and applicability of this rubric to the South African labour market could be tested if appropriate data from firms were available. 
The dominant view of unemployment in developing countries is that much open unemployment is due to search and is voluntary (Harris and Todaro, 1970), i.e. people choose to remain jobless while they search for a good job. If search for a formal sector job from the unemployed state is more efficient than from informal employment, those able to afford unemployment remain openly unemployed and search. However, the poor cannot afford it. Thus, if most unemployment in the economy is of the voluntary search variety, the relationship between unemployment and household income is likely to be positive because the well-off will choose search unemployment but the poor will enter informal sector employment.

However, Kingdon and Knight (2004a) find little support for the idea that people choose to be unemployed. The unemployed are, on average, substantially worse off than the informally employed - both in terms of income and expenditure and in terms of a range of indicators of well-being. This contradicts the luxury or search unemployment interpretation, whereby higher income raises the incentive to remain searching and reduces the incentive to obtain informal employment.

It might be argued that, given the disutility of work, some people prefer to substitute leisure for higher monetary income, so that their apparent deprivation cannot be used to argue that they are constrained to be unemployed. However, in order to interpret unemployment as voluntary, such people should be happier (or, at least, not unhappier) than employed people. Data show that the unemployed are very substantially (and significantly) less happy than informally employed people, suggesting that their unemployment is not due to choice. Finally the average duration of uncompleted spells of unemployment (2.2 years) is too long to sustain a person in search unemployment. The fact that the unemployed are significantly poorer and unhappier than the informally employed suggests that jobless persons' lack of entry into self employment is due to some impediments to entering the productive part of the informal work.

What are these impediments? There is a paucity of evidence on whether the informal sector is a free-entry sector and it is imperfectly understood why it is relatively small in South Africa. In a survey of 500 informal sector operators in the Johannesburg area in 1999, respondents listed crime, lack of access to credit, lack of access to infrastructure and services, and need for training as the top four constraints on their businesses. Chandra et al. (2002, pp. 26, 30) find that the informal sector operators had required substantial start-up capital (averaging over 2.5 times the average monthly earnings in the sample). New small businesses have to rely on their own financial resources: there was very little access to either formal or even informal credit. The 1999 survey suggests that government support continued to be inadequate, particularly in relation to crime prevention, investment in infrastructure, and the provision of credit and training facilities (Chandra et al., 2002, Table A2.6, pp. 18, 20, 44-5). 30\% of the informal businesses had been victims of crime in the previous year, but the number of respondents expressing concern was double that figure ${ }^{17}$. $81 \%$ of all informal sector operators (and $90 \%$ of the self-employed non-employers within that group) had never received any business assistance or training. The lack of training reflected the high cost: the few owners who had been trained had paid on average three times the average monthly earning of the sample for their training. $60 \%$ of the operators did not have access to the 'small business support centers' that had been established by central and local government. Xaba et al. (2002, p. 25) argue that the South African government's avowed support for small, medium and micro-enterprises (SMMEs) is concentrated on the formal sector and neglects the informal sector. However, these problems exist in most developing countries and do not explain the smallness of the South African informal sector.

\footnotetext{
${ }^{17}$ The prevalence of violence and insecurity in the informal sector is stressed also by Kaplinsky (1995) and Manning and Mashigo (1993).
} 
Table 10

Unemployment and informal employment

\begin{tabular}{|lccc|}
\hline & $\begin{array}{c}\text { Urban } \\
\text { unemployment } \\
\text { rate }\end{array}$ & $\begin{array}{c}\text { Employment rate } \\
\text { in the } \\
\text { informal sector (3) }\end{array}$ & $\begin{array}{c}\text { Ratio of informal sector } \\
\text { employment to } \\
\text { unemployment }\end{array}$ \\
\hline South Africa & $\mathbf{2 9 . 3}$ & $\mathbf{1 8 . 9}$ & $\mathbf{0 . 7}$ \\
Other Sub-Saharan Africa (1) & $\mathbf{1 6 . 0}$ & $\mathbf{7 4 . 8}$ & $\mathbf{4 . 7}$ \\
Benin & 10.1 & 92.8 & \\
Burkina Faso & -- & 77.0 & \\
Chad & -- & 74.2 & \\
Guinea & 12.3 & 71.9 & \\
Kenya & 16.2 & 71.6 & \\
Mali & 9.9 & 78.6 & \\
Mauritania & 31.6 & 75.3 & \\
Mozambique & -- & 73.5 & \\
Zambia & -- & 58.3 & \\
& & & \\
Latin America(1)(2) & $\mathbf{8 . 1}$ & $\mathbf{5 6 . 9}$ & \\
Argentina & 18.8 & 53.3 & \\
Bolivia & 3.6 & 63.6 & \\
Brazil & 4.6 & 57.6 & \\
Colombia & 9.0 & 55.5 & \\
Ecuador & 6.9 & 53.5 & \\
Mexico & 6.3 & 59.4 & \\
Paraguay & 65.5 & \\
Venezuela & 5.6 & 46.9 & \\
& 10.3 & & \\
Asia(1) & & $\mathbf{6 3 . 0}$ & \\
India & $\mathbf{5 . 3}$ & 73.7 & \\
Indonesia & -- & 64.9 & \\
Pakistan & 7.2 & 66.9 & \\
Philippines & 6.1 & 51.4 & \\
Thailand & 7.4 & & \\
Iran & 0.4 & -5.5 & \\
\hline & & & \\
\end{tabular}

Sources : Taken from Charmes (2000), Table 1. Charmes reports that his labour force figures are taken from the World Development Indicators, 1997 and that the figures are personal compilations of the author and are "based on official figures (published or unpublished) for National Accounts".

Notes: (1) Non-weighted arithmetical means. (2) Informal employment estimates for 1995. (3) As a share of total non-agricultural employment.

Charmes does not specify the definition of unemployment used for the included countries but it seems to be the standard ILO-recommended definition for most countries. In any case, in most countries, the gap between the narrowly and broadly defined unemployment rates is small. In South Africa, however, Charmes seems to have used the 'broad' definition of unemployment. If the narrow definition is used, urban unemployment in South Africa in 1995 was $15.7 \%$ rather than $29.3 \%$ (StatsSA, 1998) and, thus, the ratio of non-agricultural informal employment to unemployment would be 1.2 instead of 0.7. However, by 1998, the narrowly measured unemployment in South Africa was $26 \%$ with relatively little change in the size of the informal sector, so that the ratio in 1998 is of the order of 0.7. Although the size of informal sector employment has clearly changed over time in South Africa, it has not changed so dramatically as to change the qualitative conclusion that South Africa is an international outlier in terms of the smallness of the size of its informal sector.

Since much of the agricultural labour force in developing countries is engaged in small-scale or subsistence agriculture, the share of the informal sector in the agricultural labor force is expected to be even greater than that in the non-agricultural labor force reported here. For example, for India, the share of the informal sector in the nonagricultural labor force is $79 \%$ but its share in the total labor force is 92\% (Kulshreshtha and Singh, 1998). 
One thing that does distinguish South Africa is the observed effectiveness of enforcement of labour regulations. Labour market institutions such as Industrial Councils (now called Bargaining Councils) and Wage Boards set sectoral minimum wages and stipulate working conditions in many industries in South Africa. These minimum wages and stipulations are applied to all firms in the industry and region, irrespective of size, via the 'extension' provision. There are serious penalties for flouting the agreements of these institutions (Moll, 1996; Nattrass, 2000). Such provisions impose a burden of high labour costs on small firms and it is likely that they would seriously inhibit the entry and growth of such firms. This is one explanation for the large average size of firms in South Africa. These institutional features may inhibit small firms but they should not inhibit individual entrepreneurship, i.e., owner-operators.

The lack of African self-employment is, to some extent, a legacy of apartheid. Historically the apartheid system repressed the informal activities of black South Africans through such restrictive legislation as the Group Areas Act, harsh licensing, strict zoning regulations, and effective detection and prosecution of offenders. Bouts of slum clearance and other periodic attacks on the illegal spaces within which informal enterprise thrived, served to rid South African cities of black-dominated informal sector niches that were construed as hazardous to public health and stereotyped as unsightly and unsanitary (Rogerson 1992). While these restrictions have been progressively lifted since the mid-1980s, there were lingering licensing controls and restrictive bye-laws in many urban centres in the late 1990s. Moreover, repression and disempowerment of Africans under apartheid would have inhibited the development of entrepreneurial and social skills and of social networks. These factors are important for confidence in entering the self-employed sector and for success in it.

Several authors note that many activities in the so-called informal sector of developing countries are highly stratified, requiring skills, experience and contacts, with identifiable barriers to entry. For example, petty trading often has highly structured labor and product markets with considerable costs of entry. Banerjee (1986) found that even in urban India, with its large self-employment sector, entry is not easy. Even when skill and capital are not required, entry can be difficult because of the presence of cohesive networks which exercise control over location and zone of operation. Support for the idea that employment in the informal sector requires skills and capital also comes from Latin America. In his work on Latin American countries in general and on Mexico in particular, Maloney $(1999,2002)$ questions whether the informal sector in Latin America largely comprises involuntary, disadvantaged and under-paid workers, and finds evidence for viewing it more as an unregulated entrepreneurial sector, voluntarily entered even at the expense of lower income. However, in arguing that informal sector workers tend to be older and to enter from the formal sector after they have accumulated knowledge, capital and contacts, he recognizes that lack of experience and capital can be barriers to entry that deter participation in the informal sector. While more research is needed on the issue, the above evidence provides pointers as to why the South African informal sector is so small compared with other countries.

Despite the fact that the informal sector in South Africa continues to be small in comparison to other developing and middle-income countries, it has experienced growth in recent years.

Nevertheless, there is considerable scope for the further development of a productive informal sector - comprising medium and small-scale enterprises (SMMEs). These have the advantage of often being more labour-intensive and less capital-intensive than large scale enterprises, and of promoting black economic empowerment.

The existing policy support to SMMEs in South Africa has focused on the provision of finance and facilities, though its impact has not been systematically evaluated. However, while finance removes one obstacle, the SMME sector faces another, probably more important, obstacle to its 
development, namely unfair competition. The ergo omnes provision, which requires each Bargaining Council agreement about minimum wages and working conditions to be extended to all (including small) employers in the industry and area, places SMMEs at a disadvantage: small producers are placed under crippling labour market burdens. Removing this provision could provide the greatest boost yet to the development of the productive part of the self-employment sector in South Africa.

\section{Policy conclusions}

This paper has concentrated on the crucial issue of overwhelming importance - unemployment and its rise. We have ignored or skimmed over the lesser labour market issues which, although important in themselves and deserving policy attention in their own right, could detract from the one issue that could sweep everything else away. As cautioned in the introduction, we have tried to tease out the main trends in unemployment and related labour market measures from the available imperfect and fragile data. We have tried to be judicious in the use of the statistics and of other authors' analyses - justifying our choices when there is conflicting evidence.

The legacy of history continues to have long term effects on the labour market. Economic stagnation in the two decades before democracy, the extreme economic inequality, and the development of a powerful trade union movement, all continue to have their impact today. Since it took office, the ANC Government has had little political and economic room to manoeuvre in its economic policies (Gelb, 2004). The two basic policy choices were: what points on the tradeoff between economic efficiency and social equity, and between long and short run benefits, to choose? The government has resisted the calls of populism and has tended to stress efficiency and long term considerations in most areas of economic policy (such as trade liberalisation, deregulation, and the encouragement of the private sector) that underlie the GEAR.

Nevertheless, the labour market outcomes of this set of policies have been unsuccessful. That raises the broad question: to what extent are the general economic policies and to what extent are labour market policies to blame for this? Our argument is that the two are intertwined: labour market policies can have adverse effects in themselves but they can also reduce the effectiveness of the GEAR policies.

There is potential for any economy to enter a virtuous circle of economic growth or get caught in a vicious circle of relative stagnation. For instance, Japan, having been in a self-fulfilling virtuous circle of high investment, fast-growing exports, and business confidence which produced rapid economic growth for four decades, in the 1990s entered a vicious circle of low investment, low confidence, and economic inertia from which it has not yet emerged. And several East Asian countries have in recent years broken out of stagnation and achieved selfsustained economic growth. In the last decade, South Africa has been, and still remains, on a knife-edge: the economy could go either way. The danger is that low business confidence and inadequate investment make things worse in the labour market, which in turn by various processes of cumulative causation feeds through into self-fulfilling pessimism about the economy.

In explaining the rise in unemployment and its possible cures, we placed our emphasis on the slow growth of the economy, and thus slow growth in the demand for labour relative to the rapidly growing supply, and the need above all else to pursue economic policies to help raise the economic growth rate. The rapid divergence in the supply and demand for labour places a great burden of adjustment on the labour market, which would put a great strain on even the most 
flexible of labour markets. In fact, it appears that major segments of the South African labour market are not flexible. This imposes an excessive burden on the more flexible segments, the result of which has been rising unemployment.

The system of labour market governance that has been put in place over the last decade has been built on consensus and co-operation. However, it has involved largely government, formal sector employees, and employers. Another party, potentially affected but not adequately represented in developing the consensus on governance, is the growing number of informal sector poor and the unemployed poor.

The system of labour market governance embodied in the various pieces of legislation - such as the Labour Relations Act of 1995, the Basic Conditions of Employment Act of 1997, and the Employment Equity Act of 1999 - establish a framework which would be appropriate, indeed admirable, in a fully employed economy with little labour market segmentation. It is arguably less appropriate in South African conditions of unemployment and extreme labour market segmentation. The danger is that in protecting the rights of formal sector workers, the legislation and its implementation may harm the interests of those outside the formal sector. Wellintentioned labour laws can have unfortunate unintended labour market consequences. In particular, they may discourage employment (a static effect) and discourage investment (a dynamic effect). It is an uncomfortable fact that a government which espouses trade liberalisation must be prepared when necessary to espouse also a good degree of labour market liberalisation.

The measurement of potential ill-effects of labour legislation is difficult and well-established research results on this issue are not yet available. It is certainly the case, however, that many employers complain about such constraints on their decisions as the legal and procedural requirements with respect to hiring and firing of workers, the extent of union power to raise wages or disrupt production, the extension of bargaining agreements, and the 'hassle factor' arising from the labour relations legislation. While it is natural for survey respondents to stress the importance of things they dislike, complaints of this sort should not be ignored. Acted upon, these complaints can result in hiring fewer workers, substituting capital for labour, diverting managerial resources from the main task, depressing business optimism and discouraging investment. In this way the inflexibilities of the labour market may exacerbate not only income inequalities but also the underlying problem of inadequate employment creation. However, efficient managers could be expected to try to circumvent the problems that they perceived, for instance by hiring casual workers and employing sub-contactors. In this way the problems are reduced but not removed.

There is empirical evidence that crime has increased in South Africa at the same time as unemployment as risen (SAPS, 2004; Masuku, 2003). The rise in unemployment may force more people into illegal ways of getting income. A World Bank survey of 600 firms in the Greater Durban Metropolitan Area in 2002/3 (Devey, Rajaratnam, Valodia and Velia, 2003) found that crime and theft was listed as the top constraint on firm growth. This can produce another vicious circle: a higher crime rate can reduce prospective profits, sap business confidence, and lead to a brain drain. Economic growth, and thus the labour market outturn, can therefore suffer.

Our main conclusions are four-fold. First and foremost, it is crucial to pursue a set of policies that promote South Africa's rate of economic growth. Government should bear constantly in mind the implications for economic growth prospects of all its policies - whether these are general economic policies, or labour market policies, or even policies on international relations (such as those on relations with Zimbabwe), crime or health (e.g. on HIV-AIDS). 
Second, labour market regulations require reconsideration, giving greater weight to the concerns of employers and investors, and also to the interests of those - the unemployed and informally employed poor - who are beyond the reach of the labour institutions but can be hurt by them nevertheless. For instance, the removal of the ergo omnes provision for the extension of Bargaining Council agreements to all (including small) employers could have a powerful effect on promoting the SMME sector by removing the burden of high labour costs on small firms.

Third, if labour market statistics are to be used effectively for policy purposes, their deficiencies and problems need to be addressed by means of thorough interaction among StatsSA, policymakers, and independent researchers. Lack of appropriate data hinders analysis of important issues that impinge on unemployment. For instance, we can know little about entry into, exit from and duration of unemployment across groups, and to what extent high reservation wages are responsible for unemployment. Appendix 4 lists some of the ways to improve the data base for answering questions related to the causes and consequences of unemployment.

Fourthly, there is need for investigation of how active labour market policies - which were formulated largely in the absence of local evidence - have performed. For instance, the policy on skills promotion is based on the supposition that skills raise employment chances but, to our knowledge, this has never been rigorously tested in South Africa. Similarly, it has been assumed that public works programmes improve the employability of rural unemployed persons but, again, this has not been tested or the question asked as to which types of PWP models are the most effective in raising post-participation employment chances of the unemployed. The Department of Labour could commission such impact evaluation studies to assist better policy design in the future. 


\section{References}

Abedian, I. (2004) "Beyond Budget 2004: Job Creation and Poverty Alleviation in South Africa: What Should we be Doing? Public Symposium, Institute for Justice and Reconciliation, Breakwater Lodge/UCT Graduate School of Business, Cape Town, March.

Altman, M. (2002) "Progress in Addressing Employment and Unemployment", Prepared for Presidency, Policy Coordination and Advisory Services, as part of the 10 year policy review and strategic planning.

Banerjee, B. (1986). Rural to Urban Migration and the Urban Labour Market: A Case Study of Delhi, Bombay: Himalaya Publishing House.

Besley, T., L. Haddad, J. Hoddinott and M. Adato (2004) "Community Participation and the Performance of Public Works Prorgammes in South Africa”, IFPRI, Washington D.C.

Bhorat, H. (2002) "Employment and Unemployment Trends in Post-Apartheid South Africa", Paper Prepared for the Presidency 10-Year Cabinet Review Process, $2^{\text {nd }}$ Draft.

Bhorat, H. and Leibbrandt, M. (1998). 'Estimates of Wage-Employment Elasticities for South Africa', unpublished.

Bhorat, H., Lundall, P. and Rospabe, S. (2002). 'The South African Labour Market in a Globalizing World: Economic and Legislative Considerations', Employment Paper 2002/32, Geneva: International Labour Organization.

Black and Rankin (1998) "On the Cost-Increasing Effects of the New Labour Laws in South Africa", South African Journal of Economics, Vol. 66:4, pp. 452-63

Bowles, S. and Heintz, J. (1996). 'Wages and Jobs in the South African Economy: an Econometric Investigation', Department of Economics, University of Massachusetts.

Bryson, A., R. Dorsett and S. Purdon (2002). "The Use of Propensity Score Matching in the Evaluation of Active Labour Market Policies: A Study carried out on behalf of the Department for Work and Pensions", Working Paper Number 4, Policy Studies Institute and National Centre for Social Research

Casale, D and Posel, D. (2002) 'The Continued Feminisation of the Labour Force in South Africa: An Analysis of Recent Data and Trends.' South African Journal of Economics, Vol. 70(1), 156-184.

Casale, D. (2004) "What has Feminisation of the Labour Market 'Bought' Women in South Africa? Trends in Labour Force Participation, Employment and Earnings, 1995-2001", Journal of Interdisciplinary Economics, 15: 251-75.

Casale, D, C. Muller and D. Posel (2005) "Two Million Net New Jobs: A Reconsideration of the Rise in Employment in South Africa, 1995-2003”, South African Journal of Economics, forthcoming.

Chandra, V., L. Moorty, B. Rajaratnam and K. Schaefer (2000) "Constraints to Growth and Employment in South Africa. Report No. 1: Statistics from the Large Manufacturing Firm Survey", Discussion Paper 14, Informal Discussion Papers on Aspects of the Economy of South Africa. World Bank. 
Chandra, V., J. Nganou (2001) "Obstacles to Formal Employment Creation in South Africa: Evidence from Recent Firm Surveys". Paper presented to DPRU Conference, Johannesburg, November.

Chandra, V., J. Nganou and C. Noel (2002) Constraints to Growth in Johannesburg's Black Informal Sector: Evidence from the 1999 Informal Sector Survey. World Bank Report No. 24449-ZA, June.

Charmes, J. (2000). Informal Sector, Poverty and Gender: A Review of Empirical Evidence: Background paper for World Development Report 2001. Centre of Economics and Ethics for Environment and Development, University of Versailles-St Quentin en Yvelines.

Cichello, P., G. Fields and M. Leibbrandt (2002). Earnings and Employment Dynamics for Africans in Post-Apartheid Kwazulu Natal. Forthcoming in Journal of African Economies.

Devey, R. Skinner, C. \& Valodia, I. (2002). The Informal Economy in South Africa: Who, Where, What and How Much?. Paper presented to the DPRU Conference on Labour Markets and Poverty in South Africa, Johannesburg, 22-24 October, 2002. Forthcoming in Transformation.

Department of Public Works (2004) "Expanded Public Works Programme", presentation by Dr. Sean Phillips, Director of the EPWP, Midrand, $25^{\text {th }}$ February.

Fallon, P. and Lucas, R. (1998). 'South Africa: Labor Markets, Adjustment, and Inequalities', Discussion Paper no. 12, Informal Discussion Papers on Aspects of the Economy of South Africa, Southern Africa Department, World Bank, Washington D.C.

Felton, Michael (2003) The Skills Gap: Research into Workplace Skills of Further Education Students and Labour Market Requirements in Today's South Africa, DFID Research Report.

Fields, G., Leibbrandt, M. and Wakefield, J. (1999). 'Key labour market elasticities in South Africa', report commissioned by the South African Department of Finance.

Galasso, E., M. Ravallion and A. Salvial (2002) "Assisting the Transition from Workfare to Work: A Randomized Experiment", World Bank mimeo.

Gelb, Stephen (2004) "Inequality in South Africa: Nature Causes and Responses", The Edge Institute, Johannesburg.

Harris, J. \& Todaro, M. (1970). Migration, Unemployment, and Development: A Two-Sector Analysis. American Economic Review, 60(1), 126-42.

Hoogeveen, J. and B. Özler (2004) "Not Separate, Not Equal: Poverty and Inequality in PostApartheid South Africa", World Bank mimeo, presented to the NEUDC Conference, Montreal, October.

Kingdon, G. and J. Knight. 1999.“The Spatial Relationship Between Wages and Unemployment in Developing Countries: The Case of South Africa", WPS/1999-12, Centre for the Study of African Economies, University of Oxford. 
Kingdon, G. and J. Knight. 2004a. "Unemployment in South Africa: The Nature of the Beast", World Development, 32, No. 3: 391-408, March.

Kingdon, G. and J. Knight. 2004b. "Race and the Incidence of Unemployment in South Africa", Review of Development Economics, 8, No. 3: 198-222, May.

Kingdon, G. and J. Knight. 2005 "Measuring Unemployment When Unemployment is High", Labour Economics, forthcoming.

Kulshreshtha, A. C. \& Singh, G. (1998). Contribution of Informal Sector in the Indian Economy. New Delhi: Central Statistical Organisation.

Leibbrandt, M., J. Levinsohn and J. McCrary (2004) "Incomes in South Africa Since the Fall of Apartheid”, draft mimeo, May. University of Cape Town and University of Michigan.

Lundall, Paul (2003) "Sector Education Training Authorities and the Delivery of Training: Preliminary Remarks on the New Skills Dispensation in South Africa", Working Paper 03/79, Development Policy Research Unit, University of Cape Town, August.

Maloney, W. (1999). Does Informality Imply Segmentation in Urban Labor Markets? Evidence from Sectoral Transitions in Mexico. World Bank Economic Review, 13, 275-302.

Maloney, W. (2002) Informality Revisited. Mimeo, World Bank.

Masuku, Sibusiso (2003) "For Better and for Worse: South African Crime Trends in 2002", South Africa Crime Quarterly, No. 3, March 2003.

McCord, Anna (2004) "Policy Expectations and Programme Reality: The Poverty Reduction and Labour Market Impact of Two Public Works Programmes in South Africa", ESAU Working Paper No. 8, Overseas Development Institute, London.

Meth, C. and R. Dias (2004) “Increases in Poverty in South Africa: 1999-2002”, Development Southern Africa, 21(1): 59-86.

Moll, P. (1996) 'Compulsory Centralisation of Collective Bargaining in South Africa', American Economic Review, 86 (2): 326-29.

Nattrass, N. (2000) "Inequality, Unemployment and Wage-Setting Institutions in South Africa", Studies in Economics and Econometrics, 24(3): 129-42.

Quattek, Kristina (2000?). 'The economic impact of AIDS in South Africa: a dark cloud on the horizon', reprinted with permission of ING Barings.

Rogerson, C.M. (1992). The Absorptive Capacity of the Informal Sector in the South African City. In D. M. Smith, The Apartheid City and Beyond. London: Routledge.

SALDRU (1994) “South Africans Rich and Poor", South African Labour and Development Research Unit, University of Cape Town, August.

SAPS (2004) Crime Statistics Per Category, South African Police Services, http://www.saps.gov.za/statistics/reports/crimestats/2004/crime_stats.htm . 
SARB (2004) "Quarterly Bulletin, March 2004”, South African Reserve Bank, Pretoria.

StatsSA (1998) “October Household Survey 1994-1997”, Statistical Release P0317.10. Statistics South Africa, Pretoria.

StatsSA (1999) “October Household Survey 1996”, Statistical Release P0317, Statistics South Africa, Pretoria, August.

StatsSA (2000) “October Household Survey 1999”, Statistical Release P0317, Statistics South Africa, Pretoria, March.

StatsSA (2003a) “Labour Force Survey, September 2002”, Statistical Release P0210, Statistics South Africa, Pretoria.

StatsSA (2003b) “Labour Force Survey, March 2003”, Statistical Release P0210, Statistics South Africa, Pretoria.

StatsSA (2003c) "Survey of Employment and Earnings, March 2003", Statistical Release P0275, Statistics South Africa, Pretoria.

StatsSA (2004) “Labour Force Survey, September 2003”, Statistical Release P0210, Statistics South Africa, Pretoria, March.

StatsSA (2004a) “General Household Survey, July 2003”, Statistical Release P0318, Statistics South Africa, Pretoria, May.

Tan, H. (2003) "Evaluating Training Programs: A Primer and Global Examples", World Bank Institute, Human Development Division.

Van der Berg, S. (2001) "Education and Skills Constraint", extract from a talk delivered to a conference of the Bureau for Economic Research, Cape Town, November.

Xaba, J., P. Horn, and S. Motala (2002). The Informal Sector in Sub-Saharan Africa. ILO Working Paper on the Informal Economy, Employment Sector, ILO, Geneva.

Zabalza, A. 2002. "Is there a case for government intervention in Training?". Human Capital Development and Operations Policy Working Paper, World Bank. 
Appendix Table 1

Remuneration per worker in the non agricultural sectors, according to the Survey of Employment and Earnings

\begin{tabular}{|lc|}
\hline & $\begin{array}{c}\text { Remuneration per worker } \\
\text { At constant prices }(2000=100)\end{array}$ \\
\hline 1995 & 86.8 \\
1996 & 88.8 \\
1997 & 91.3 \\
1998 & 97.5 \\
1999 & 98.4 \\
2000 & 100.0 \\
2001 & 101.7 \\
2002 & 100.4 \\
2003 & 101.2 \\
\hline & \\
Change $1995-2003(\%)$ & $15.4 \%$ \\
\hline
\end{tabular}

Source: SARB, 2004, p. S-139; 1995 figures obtained from a 2003 Quarterly Bulletin of SARB.

Appendix Table 2

Mean values of variables, by whether the worker's business is VAT registered or not, LFS Sept. 2003

\begin{tabular}{|c|c|c|}
\hline & Not VAT registered & VAT registered \\
\hline Monthly earnings & 1700.62 & 2545.23 \\
\hline Log of weekly pay & 5.271 & 5.898 \\
\hline Geometric mean of weekly pay & 194.61 & 364.16 \\
\hline Self-employed & 0.333 & 0.080 \\
\hline Union member & 0.321 & 0.340 \\
\hline Firm is registered & 0.119 & 0.963 \\
\hline Firm size (No. of regular workers) & 15.10 & 38.57 \\
\hline African & 0.830 & 0.537 \\
\hline White & 0.070 & 0.222 \\
\hline \multicolumn{3}{|l|}{ Industry } \\
\hline Agriculture, forestry, fisheries & 0.086 & 0.171 \\
\hline Mining & 0.004 & 0.095 \\
\hline Manufacturing & 0.048 & 0.182 \\
\hline Utilities (gas, electricity, water) & 0.004 & 0.009 \\
\hline Construction & 0.058 & 0.044 \\
\hline Trade - retail and wholesale & 0.196 & 0.205 \\
\hline Transport & 0.034 & 0.050 \\
\hline Finance & 0.025 & 0.114 \\
\hline Community and personal services & 0.539 & 0.126 \\
\hline \multicolumn{3}{|l|}{ Occupation } \\
\hline Managerial & 0.034 & 0.087 \\
\hline Professional & 0.045 & 0.041 \\
\hline Technical & 0.118 & 0.084 \\
\hline Clerical & 0.049 & 0.130 \\
\hline Sales & 0.114 & 0.110 \\
\hline Skilled agriculture & 0.060 & 0.014 \\
\hline Artisan & 0.107 & 0.134 \\
\hline Operator & 0.033 & 0.149 \\
\hline Elementary & 0.436 & 0.247 \\
\hline
\end{tabular}

Note: Own calculations. Firm size is calculated by imputing the mid-points of categories in question 4.16 of the LFS, sept. 2003. The largest firm size (>=50 workers) was arbitrarily assigned a value of 75 workers. 


\section{Appendix 3 \\ Results from binary probits of unemployment and of long-duration unemployment}

To discern changes in the incidence of unemployment over time, we fitted a simple binary probit equation of unemployment in Appendix Table 3a below. The marginal effects columns show that in 1995, an African person was nearly 30 percentage points more likely to be unemployed than a white person of similar observed characteristics. By 2003, this figure had risen to 36 percentage points. Thus, over the 8 year period from 1995 to 2003, the probability of unemployment for an African person rose by 6.5 percentage points more than a white person's probability of being unemployed (the last column). The chances of unemployment of other population groups have also increased vis the vis the chances of unemployment of whites. We know that the population share of whites has fallen dramatically between the 1991 and 2001 censuses - from about $16.5 \%$ to only $9.5 \%$ (Gelb, 2004). It seems possible that whites have avoided the large unemployment increases that other race groups have suffered partly by outmigration to foreign countries as they are likely to have better contacts and the capital needed for emigration.

While in 1995, possession of secondary (higher) education reduced the chances of unemployment (vis a vis those with no education) by about 5 (23) percentage points, by 2003, secondary education actually raised the probability of unemployment by 3 percentage points relative to those with no education, though people with higher education continued to be much less likely to be unemployed (their marginal effect rises minimally, by only 1.4 percentage points). Relative to those with no education, the chances of unemployment of persons with primary, junior and secondary education have all risen by about 6 to 8 percentage points. However, those possessing higher education have been largely insulated from these unemployment increases.

Relative to the base age category (ages 36-45), younger persons are now more likely to be unemployed than they were in 1995, by about 8 percentage points for those in age group 21-25 and by about 6 percentage points for those in the 26-35 age group. Vis a vis the base age group, older people - i.e. those aged $>=46$ years old - are about 3 to 4 percentage points less likely to be unemployed in 2003 than they were in 1995. This suggests that unemployment has risen largely among the young, people who are likely to be new entrants to the labour market.

Unemployment probability has fallen everywhere in relation to the situation in Gauteng, where unemployment has risen the most as was seen in Table 8. In 1995, the chances of unemployment in Northern Cape province were 17.4 percentage points higher than Gauteng but by 2003, these had decreased to only 7.7 percentage points, a fall of 9.7 percentage points. While unemployment rose in the Northern Cape by 11.5 percentage points over this period, this increase was smaller than the increase in unemployment in Gauteng.

Appendix Table $3 \mathrm{~b}$ presents a binary probit equation of long-duration unemployment, i.e. whether the unemployed individual had been unemployed for more than 3 years. The results show that controlling for age, education and location - factors that are highly correlated with race - makes a difference. For instance, raw data in Table 9 showed that in 1995, the Africanwhite difference in the incidence of long-duration unemployment was 28.6 percentage points. But once we control for age, education and location etc. in Appendix Table 3b, the Africanwhite difference falls by about one-fifth, to 22.5 percentage points (marginal effect of African in 1995 in Appendix Table 3b). However, in 2003, the raw African-white difference of 18.6 percentage points (Table 9) increases to 21 percentage points (Appendix Table 3b) when we control for other characteristics. 
While secondary and higher education reduced the chances of long-duration unemployment by about 5 to 6 percentage points in 1995, by the year 2003, possession of these levels of education did not reduce the chances of long-duration unemployment at all. Controlling for other factors, between 1995 and 2003, the chances of being long-term unemployed increased by 5 to 9 percentage points for persons with $>=$ junior education, compared with persons with no education.

The marginal effects on the age variables show that, compared to persons aged 36-45 years old, those aged 16-25 were 18 to 24 percentage points less likely to be in long-term unemployment in 1995. By 2003, the corresponding figures were 24 and 32 percentage points, respectively. The fact that younger people were substantially less likely to be in long-duration unemployment by 2003 than they were in 1995 suggests that more of the young are staying on at school and joining the labour force at higher ages.

Compared with Gauteng, the chances of long-duration unemployment increased by 13 percentage points in Limpopo, a very large change indeed. Unemployment duration also increased substantially in the Eastern Cape and North West provinces, compared to Gauteng. 
Appendix Table 3a

Binary probit of unemployment

\begin{tabular}{|c|c|c|c|c|c|c|c|}
\hline & Coefficient & $\begin{array}{c}1995 \\
t \text {-value }\end{array}$ & $\begin{array}{c}\text { marginal } \\
\text { effect }\end{array}$ & Coefficient & $\begin{array}{c}2003 \\
\text { t-value }\end{array}$ & $\begin{array}{c}\text { marginal } \\
\text { effect }\end{array}$ & $\begin{array}{l}1995-2003 \\
\text { Difference } \\
\text { in marginal } \\
\text { effect*100 }\end{array}$ \\
\hline Race & & & & & & & \\
\hline African & 1.0959 & 35.8 & 0.296 & 1.1118 & 33.7 & 0.361 & 6.5 \\
\hline Coloured & 0.6040 & 17.3 & 0.211 & 0.7042 & 17.6 & 0.275 & 6.4 \\
\hline $\begin{array}{l}\text { Indian } \\
\text { Gender }\end{array}$ & 0.2265 & 4.5 & 0.076 & 0.4129 & 7.3 & 0.163 & 8.7 \\
\hline $\begin{array}{l}\text { Male } \\
\text { Education }\end{array}$ & -0.4574 & -33.2 & -0.144 & -0.3413 & -25.1 & -0.129 & 1.5 \\
\hline Primary & -0.0020 & -0.1 & -0.001 & 0.1495 & 5.4 & 0.057 & 5.8 \\
\hline Junior & 0.0157 & 0.6 & 0.005 & 0.1764 & 6.3 & 0.068 & 6.3 \\
\hline Secondary & -0.1537 & -5.6 & -0.047 & 0.0792 & 2.8 & 0.030 & 7.7 \\
\hline $\begin{array}{l}\text { Higher } \\
\text { Age }\end{array}$ & -1.0236 & -25.5 & -0.225 & -0.6248 & -16.6 & -0.211 & 1.4 \\
\hline Age $16-20$ & 1.2110 & 38.9 & 0.450 & 1.3177 & 43.9 & 0.476 & 2.6 \\
\hline Age 21-25 & 0.8497 & 38.4 & 0.305 & 1.0077 & 46.4 & 0.386 & 8.1 \\
\hline Age $26-35$ & 0.3624 & 19.7 & 0.118 & 0.4516 & 24.8 & 0.174 & 5.6 \\
\hline Age 46-55 & -0.0923 & -3.8 & -0.028 & -0.1509 & -6.5 & -0.056 & -2.8 \\
\hline $\begin{array}{l}\text { Age } 56-65 \\
\text { Location }\end{array}$ & -0.3197 & -8.2 & -0.089 & -0.3470 & -9.2 & -0.124 & -3.5 \\
\hline Urban & 0.1705 & 10.5 & 0.053 & 0.0483 & 3.1 & 0.018 & -3.5 \\
\hline Western Cape & -0.0187 & -0.6 & -0.006 & -0.2397 & -7.4 & -0.088 & -8.2 \\
\hline Eastern Cape & 0.5049 & 18.7 & 0.174 & 0.1992 & 7.5 & 0.077 & -9.7 \\
\hline Northern Cape & 0.2445 & 6.0 & 0.082 & 0.1439 & 3.8 & 0.056 & -2.6 \\
\hline Free State & 0.0012 & 0.0 & 0.000 & 0.0063 & 0.2 & 0.002 & 0.2 \\
\hline KwaZuluNatal & 0.2541 & 9.5 & 0.084 & 0.0672 & 2.7 & 0.026 & -5.8 \\
\hline North West & 0.1904 & 5.9 & 0.063 & 0.1482 & 5.3 & 0.057 & -0.6 \\
\hline Mpumalanga & 0.2664 & 8.5 & 0.089 & -0.0074 & -0.3 & -0.003 & -9.2 \\
\hline Limpopo & 0.4860 & 14.7 & 0.171 & 0.2801 & 9.7 & 0.109 & -6.2 \\
\hline _constant & -1.7219 & -37.9 & & -1.5624 & -33.1 & & \\
\hline Log likelihood & & -22090.26 & & & -23120.13 & & \\
\hline Pseudo R-sqr. & & 0.1849 & & & 0.1842 & & \\
\hline $\mathrm{N}$ & & 44508 & & & 41906 & & \\
\hline Mean depvar & & 29.77 & & & 40.85 & & \\
\hline
\end{tabular}

Note: Omitted categories are: white population group, females, no education, age 36-45, rural and Gauteng province. 
Appendix Table 3b

Binary probit of long-duration unemployment (duration>3 years) among the strict unemployed

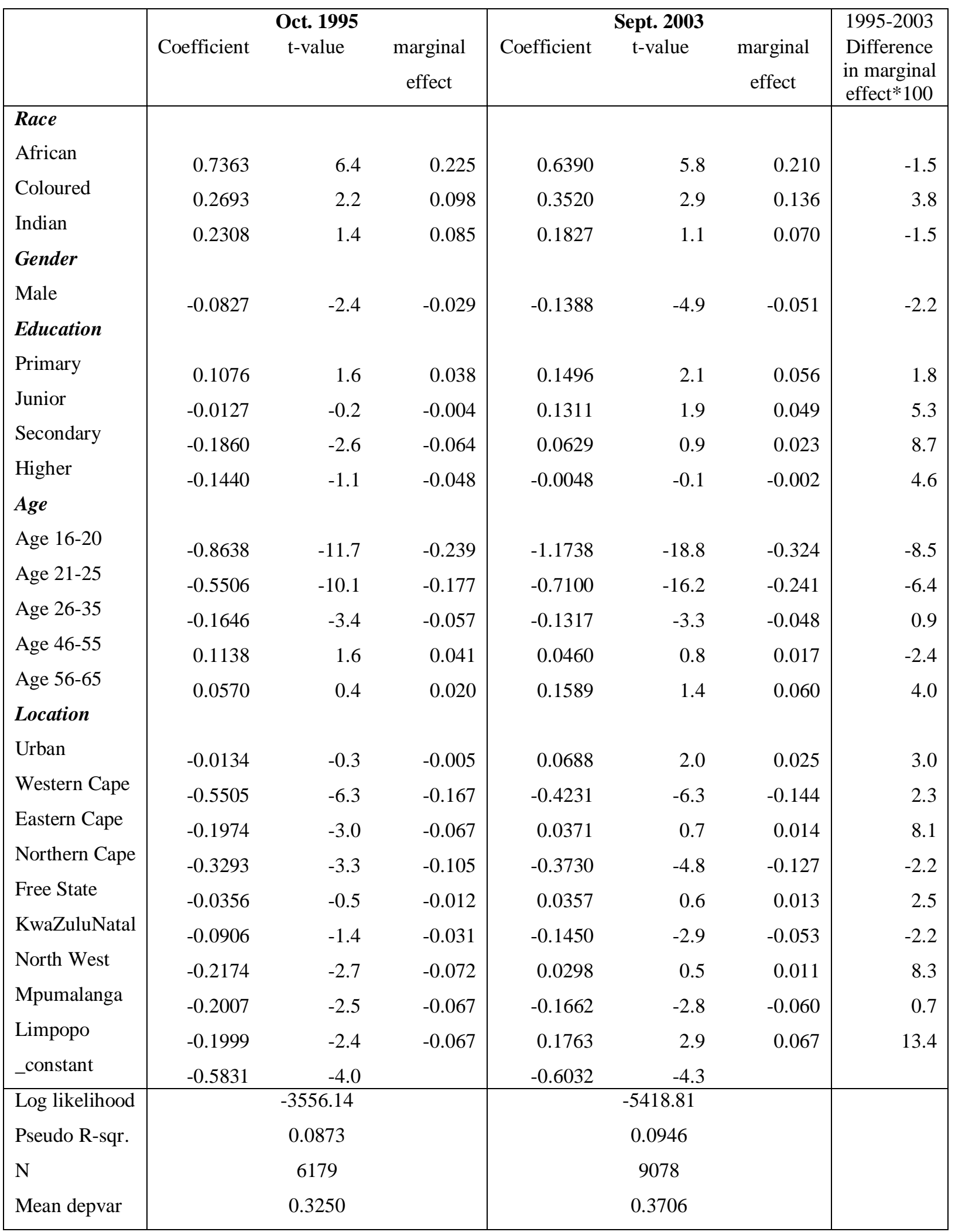

Note: Omitted categories are: white population group, females, no education, age 36-45, rural and Gauteng province. 


\section{Appendix 4 \\ Data requirements for the further analysis of unemployment and its consequences}

In attempting to understand unemployment - a crucial issue for South Africa - we encountered imperfect data. There has been tremendous improvement in the collection and availability of labour market data in the post-apartheid period. However, there are still gaps and problems which bear serious consideration in order to improve future data collection. Improving the evidence-base can have high returns: policy research can be more reliable.

1. Due to an effective lack of panel data which provides information on the same individuals over time, it is not possible to understand a number of aspects of unemployment, such as duration of completed spells of unemployment and entry into and exit from unemployment. While the Labour Force Surveys are intended to have a rotating panel, person identifiers are not lined up appropriately between the different waves of the survey to permit the construction of a reliable panel. This can be virtually costlessly addressed.

2. The survey question to determine duration of unemployment asks how long an individual has been seeking work. Those who have become discouraged may interpret this to mean 'how long has the individual been searching for work' and may either not reply or reply that they have not searched, which might be coded as the lowest duration category, e.g. 'less than one month'. Secondly, data is available only in categorized form, rather than as a continuous variable. For instance, in the 1995 OHS, the categories were less than a month, 1-6 months, 6-12 months, 1-3 years and $>3$ years, which leads to loss of information. Thirdly, the categories of unemployment duration are not chosen in a way that leads to a good distribution of the unemployed across the categories: more than two-thirds of the unemployed have duration greater than 1 year, and nearly two-thirds have duration more than 3 years. The top two duration categories deserve breaking up into more detailed bands but instead, the Labour Force Surveys have provided sub-divisions of the categories for duration less than 1 year. Lastly, the question on duration of unemployment is asked only of the strictly unemployed in certain surveys, e.g. the Labour Force Survey of Sept. 2003. Duration of unemployment data needs to be collected for the discouraged unemployed as well.

3. In both the October Household Surveys and the Labour Force Surveys, the question about method of job-search lists 'through friends and relatives' as a valid method of job-search. However, in both surveys the question about the method of job-search comes after the question about whether a person did any job-search in the past week/4 weeks. If a person reports that they have not taken any action to look for work in the past four weeks, they are not asked the next question, about method of job-search. Since people who are waiting to be called by employed relatives or friends (or indeed people waiting for recruiting lorries to arrive) would not know whether such waiting would constitute a valid form of job-search in the eyes of the enumerator, they may well say 'no' to the question asking whether they engaged in any jobsearch in the relevant period. Indeed, according to the Special Retrospective Survey of Employment and Unemployment of 1997, the main method that people had in mind regarding seeking work "turns out to be a rather stringent criterion. It involved going in person to workplaces and asking for work. $72 \%$ of unemployed people who had looked for work four weeks prior to the interview had taken this step..." (StatsSA, 1998, p13). The ordering of questions may therefore have excluded from the 'searching unemployed' people who were nevertheless doing their best to find work. The sequencing of the questions needs to be rethought to avoid this problem. For instance, question 3.7 in the September 2003 LFS could be dropped and question 3.8 could be asked with a new option at the end: "not looked for work in any of the ways listed above".

4. There are no reliable data on reservation wages. This means that we cannot know which individuals/ what proportion of the unemployed have unrealistically high wage expectations, i.e. wage expectations above what their skills and endowments can reasonably fetch in the labour market. A reservation wage question is needed that collects information on expected hours of work per period, maximum acceptable 
distances to work, past wages, and past wage offers rejected, and which makes a dedicated attempt to obtain data on the minimum wage that would be acceptable for work rather than the expected, fair or bargaining wage.

5. While the October Household Surveys collect information on earnings and incomes, the data are collected in a somewhat different form from year to year and this undermines reliable over-time comparisons. For instance, certain October Household Surveys ask for earnings information in a continuous form, some allow for a mixture of continuous and categories responses. The Labour Force Survey of September 2003 does not ask an earnings question separately for the self-employed while other surveys do. It would assist future analysis of labour market trends if good practice - learnt on the basis of data collection experience so far - is consistently applied in future labour force surveys.

6. Data is not suitable for the analysis of trends in poverty. For instance, when asking for information on total household income and total household expenditure, the questionnaires ask the respondent to identify an expenditure or income category from 8 pre-coded expenditure/income intervals. In the OHS97 dataset, $95.5 \%$ of all households responded to the household expenditure question when the answer was requested as an amount rather than as an expenditure category. In the OHS99 data, where the question asked for an expenditure category rather than an amount, only $93.1 \%$ of households responded. Thus, asking for an actual amount does not reduce the response rate, rather it marginally raises it. Moreover, it is far more useful since it captures the variations in expenditure across households: asking for a few income categories reduces the variability of the data and is less useful.

7. If household expenditure data must be collected in categorised form, it is useful if the categories to be included are thought through and justified carefully. The frequency table (Appendix Table 4) below shows that in OHS99 data, nearly three quarters (72\%) of all South African households fall in the lowest three expenditure categories (the first, second and third expenditure categories were Rand 0 -Rand 400 ; R400-R800 and R800-R1200). The remaining 5 expenditure categories contain only $28 \%$ of the households. This suggests that the expenditure categories were not well-chosen. Given that SALDRU 1993 data and, indeed, the OHS97 data both have a continuous (rather than a categorised) household expenditure variable, the distribution of expenditure in those surveys would have provided a good guide when deciding what expenditure categories to create for the OHS99 questionnaire. For instance, the distribution of the OHS97 household expenditure variable shows that the $25^{\text {th }}$ percentile of household expenditure was at R350, i.e. the poorest $25 \%$ of households had a monthly expenditure below R350. The $50^{\text {th }}$ percentile was at R600 and the $75^{\text {th }}$ percentile at R1100. The same expenditure categories exist in the Labour Force Surveys as in the October Household Surveys, suggesting that persons who design the questionnaires are not learning from the analysis of previous data.

\section{Appendix Table 4}

\section{OHS99 - Total household monthly expenditure category (all households)}

\begin{tabular}{cccrr} 
TOTEXP-CATEG. & Frequency & Percent & $\begin{array}{r}\text { Cumulative } \\
\text { Frequency }\end{array}$ & $\begin{array}{r}\text { Cumulative } \\
\text { Percent }\end{array}$ \\
\hline 1 & 6802 & 27.96 & 6802 & 27.96 \\
2 & 7096 & 29.16 & 13898 & 57.12 \\
3 & 3654 & 15.02 & 17552 & 72.14 \\
4 & 2276 & 9.35 & 19828 & 81.49 \\
5 & 1449 & 5.96 & 21277 & 87.45 \\
6 & 1835 & 7.54 & 23112 & 94.99 \\
7 & 901 & 3.70 & 24013 & 98.69 \\
8 & 318 & 1.31 & 24331 & 100.00 \\
& Frequency Missing $=1803$ &
\end{tabular}


OHS99 - Total household monthly expenditure category (African households)

\begin{tabular}{cccrc} 
TOTEXP-CATEG & Frequency & Percent & $\begin{array}{r}\text { Cumulative } \\
\text { Frequency }\end{array}$ & $\begin{array}{r}\text { Cumulative } \\
\text { Percent }\end{array}$ \\
\hline 1 & 6339 & 33.53 & 6339 & 33.53 \\
2 & 6238 & 32.99 & 12577 & 66.52 \\
3 & 2882 & 15.24 & 15459 & 81.76 \\
4 & 1630 & 8.62 & 17089 & 90.38 \\
5 & 825 & 4.36 & 17914 & 94.74 \\
6 & 729 & 3.86 & 18643 & 98.60 \\
7 & 210 & 1.11 & 18853 & 99.71 \\
8 & 55 & 0.29 & 18908 & 100.00 \\
& \multicolumn{2}{c}{ Frequency Missing $=1072$} \\
\end{tabular}

